Meadowlands in time: Re-envisioning the lost meadows of the Rother valley, West Sussex, UK

\author{
Alastair W. Pearson ${ }^{1}$ and Philip J. Soar ${ }^{2}$
}

${ }^{1}$ Department of Geography, University of Portsmouth, Portsmouth PO1 3HE, UK. alastair.pearson@port.ac.uk (corresponding author)

$+44(0) 2392842472$

${ }^{2}$ Department of Geography, University of Portsmouth, Portsmouth PO1 3HE, UK. philip.soar@port.ac.uk $+44(0) 2392842482$ 


\title{
Meadowlands in time: Re-envisioning the lost meadows of the Rother valley, West Sussex, UK
}

\begin{abstract}
Historically, meadows provided an essential crop of hay and common grazing in a delicately managed sustainable system in harmony with their environment and were of vital importance to the agricultural cycle of farming communities. Using archival and remotely sensed data, this paper provides a speculative re-construction of a former floodplain water management system and examines the changing fortunes of the floodplain meadows of the Rother valley, West Sussex, revealing the process of change in both the physical and cultural landscape. The inevitable decline of the floodplain meadows of the Rother was part of a nationwide transformation brought about by the introduction of new farming practices operating in a fastchanging tenurial landscape, dominated by the growth of landed estates where commoners' rights were viewed with growing contempt. Today, the current vista of the Rother reveals only remnants of the past landscape where marginal habitats, riparian fringes and meadows have made way for a monoculture of permanent pasture of poor conservation value, supporting low biodiversity and offering little to mitigate against flood risk and poor water quality. If floodplain meadow reinstatement is to be considered as part of a catchment-wide programme of landscape restoration measures then the results of this historical landscape analysis could act as a 'guiding image' for environmental managers and policy makers and a platform to rekindle once again community engagement with its landscape.
\end{abstract}

\section{Keywords}

Meadows, George Wyndham, $3^{\text {rd }}$ Lord Egremont, Rev. Arthur Young, tithe surveys, land use, catchment, floodplain restoration, Rother, West Sussex, Rother Navigation 


\section{Introduction}

In his insightful and lyrical meditation Meadowland: The Private Life of a Field, John LewisSempel bemoans the detrimental impact meadow loss has had on the British landscape. He asks:

When khaki men on the Somme or in the Burmese jungles thought of their homeland, did they not picture wildflower-strewn meadows with cottages and rolling hills? (Lewis-Sempel 2015, p. 14)

Though the decline of meadows is difficult to quantify due to a lack of reliable baseline data (Riley, 2005), their decline is undeniable with one estimate suggesting that as much as $97 \mathrm{per}$ cent of the species-rich grassland habitats including meadows and calcareous grasslands were lost between 1930 and 1984 (Fuller, 1987). Whilst traditionally managed meadows have almost disappeared, there is a growing appreciation of them as "places which provide opportunity for rest, inspiration, appreciation of aesthetic beauty, quiet reflection and spiritual experience' (Rothero et al. 2016, p. 10). The ecological qualities of meadows are well documented (Cook et al. 2004; Cummings 2007; Cutting \& Cummings 1999) and many current initiatives are striving to restore, preserve and enhance meadowlands (Cook \& Cutting 2008; Rothero et al. 2016). Arguably, though, the disappearance of the common meadows has had an even greater impact on the cultural landscape, marking the end of a delicately balanced way of life, of communal efforts to survive the harsh realities of a rural existence that had survived since the Middle Ages. The last decade has witnessed a mounting case to embed landscape history studies within the planning process (Marcucci 2000) and mapping the physical extent of meadows is essential if future restoration is to be contemplated. The revealing of the complex hidden cultural landscape could enhance the prospect of sustainable landscape restoration aspirations with a deeper social perspective that recognises the relations between people and their environments (Antrop 2005) and rests on engagement with local communities.

Telling the story of the meadows of the lower Rother also provides a fascinating insight into the process of change in the landscape instigated by what Richard Muir terms 'interventions' that 'ripple and rebound around the countryside...in directions that may never have been envisaged by the perpetrators of change' (Muir 2003, p. 401). As we shall see, the impression left on the landscape by farmers responding to national concerns in meeting the 
needs of a rising population were matched by an individual land owner, enthused by the latest ideas on agricultural improvement.

Drawing on archival, field and remotely sensed evidence, this paper examines the extent, assemblage and management structure of the Rother floodplain meadows from the earliest surviving evidence to a point just prior to their demise in the mid-nineteenth century. To trace the origin and development of the meadows, we can draw on a wide range of documentary sources familiar to landscape historians (Sheail 1980). The bulk of the evidence comes from the mid-nineteenth century tithe surveys, plans of the Rother navigation and large-scale local plans and maps commissioned by major landowners. The value of the tithe surveys has been enhanced here by their input into a geographical information system (GIS), enabling the production of maps tailored to our specific research questions, tabulation of statistics on any theme contained within the apportionments and the possibility of undertaking sophisticated modelling of the data if required. ${ }^{i}$ Finally, consideration of the field evidence, coupled with analysis of high resolution LiDAR (Light Detection And Ranging) ${ }^{\text {ii }}$ data using the catchment tools available in Golden Software's Surfer ${ }^{\circledR}$ surface mapping system, allow us to conjecture the original water management system of the floodplain meadows and thus provide a blueprint for future landscape restoration efforts.

\section{Systems of Water Meadow Management}

Anthea Brian (1993) defines meadow as grassland that is 'allowed to grow up, flower and set seed and is then cut for hay' whereas 'pasture' she defines as 'grassland that is grazed on and off through the growing season', the former of floristically rich diversity, the latter contrastingly low (p. 58). The over-wintering of livestock depended on a good hay harvest and animal manure was an essential fertiliser for the arable fields, thus a reliable supply of hay ensured winter feed for the oxen and horses, the indispensable working farm animals. Whilst all types of meadow were highly valued, it was the superior floodplain meadows with their deep fertile soils, replenished by mineral and nutrient-rich silt deposits that were keenly protected and managed. The level of management and the sophistication of the techniques used to regulate the water varied from place to place, one of the chief factors being the environmental context. Meadows, or more precisely floodmeadows, would benefit from seasonal inundation by a river with little intervention. An easy way to improve the grassland further was to control a watercourse at its exit so that water could be impounded and flood 
the meadows upstream, the so-called 'floating upwards' method. The flood water would be released once it was judged that sufficient time had been allowed for the sediment to have been deposited. Though suitable for flat river floodplains, these methods provided little regulation of water flow and risked stagnation with anaerobic conditions not conducive to grass growth. Warping, the controlled flooding of silt-laden water in low-lying marshlands such as the Somerset Levels and particularly the Humber Estuary and its tributaries, was an effective and inexpensive way of improving reclaimed pastures, a technique introduced during the eighteenth century that became more effective with the introduction of the steam pump to control the duration of the inundation (Smith 2012; Williams 1970, 1972). However, the prime purpose of this latter technique was to increase and, in many cases, create a soil layer for pasture or even tillage rather than the manuring and irrigation of existing meadows (Loudon 1825).

In the eastern South Downs, the slow-moving lower reaches of the Arun, Adur, Ouse and Cuckmere rivers provided medieval farmers and landowners with the opportunity to create common water meadows, locally known as brooks. These rivers regularly flooded the wide alluvial floodplains during winter months and, if properly managed, offered rich pasture and an 'early bite' of grass for the lambs in spring. However, the control of the floodwaters was a continuous struggle, especially during winter months when much of the brookland would be inundated for months, fit only for fishing and fowling (Brandon 2006). During the sixteenth century Dutch engineers were influential in the design of drainage schemes including the canalisation of the main channels to improve flow. Nevertheless, adequate control of these large rivers often proved beyond the capability of the technology of the time.

Thomas Davis (1811) in his Review of the Agriculture of Wiltshire provided a detailed description of two rather more sophisticated water management techniques that provide something more akin to irrigation: catchworks and bedworks (or 'flowing meadows' according to Davis). Catchworks consisted of a head main cut sub-parallel to the contour of the valley slope to provide a gradient to the flow in diverting water from a river or its tributary. Water would overtop the head main, having been stopped at its end via hatches or turves, or pass through gaps cut in its side before flowing down the hillside and through the grass by gravity. Parallel catch drains at intervals of between 20 and 30 feet would partially collect the flowing water and redistribute it more evenly over the hillside in a cascading 
management technique, in turn reducing the risk of gully formation. Water would eventually reach the main drain at the foot of the slope for carriage to lower level meadows.

The focus of past research has predominantly been on the more sophisticated and intricate patterns of interlocking floated bedwork systems on the wide and level floodplains of the chalklands of Dorset, Wiltshire and Hampshire (Bettey 2003, 2007; Bowie 1987; Cook et al. 2003; Cook \& Williamson 2007; Stearne \& Cook 2015). Floated bedworks comprised a complex system of sluices and hatches that carefully regulated the diversion of water from a river into a main carrier or headmain and thence into secondary channels or directly into shallow 'carriers' flowing along the crest of parallel ridges. Blocking the flow at the end of the carriers caused overtopping and facilitated the sustained but gentle watering down the sides of the ridges, or 'panes', where collecting furrows would then pass residual water onto a tail drain before returning to the river. In the most sophisticated floated bedwork systems there was careful control of the water flow over the grass to ensure that the temperature of the ground would be raised above $5^{\circ} \mathrm{C}$, promoting germination and growth. Protection from frost and increased oxygenation would also yield an early bite for grazing sheep. Other benefits included the eradication of moles, weeds and mosses from the sward.

Water meadows thus afforded a fundamental and crucial component of the agricultural system, particularly in the thin chalkland soils of central southern England where large flocks of sheep (more importantly their dung) were essential to maintain sufficient fertility to sustain the wheat and barley crops from which farmers derived most of their income, the so-called 'sheep-corn' farming system (Bettey 1999).

\section{Origins, Development and Decline of the Meadows in England}

According to McDonald (2007a) archaeological evidence in the Thames valley demonstrates that floodplain grasslands were important to Middle Bronze Age and later Iron Age pastoralists. Following the introduction of hay making during the sixth century AD, watered meadows were the most highly valued type of land recorded in the Domesday Book and a vital component in the open field system of the Middle Ages. The allotting of strips of arable land accompanied by the right to graze livestock and cut hay on common flood meadows was typical of the agricultural system throughout England.

Early use of river floodplains for improved grazing and hay harvesting rested on the periodic natural flooding from the river. The digging of ditches would have been necessary, as much 
to drain the meadows as to irrigate them, and weirs and hatches were introduced to facilitate more efficient and precise management of the water.

More advanced techniques developed through the desire to improve the quality and consistency of the meadow grass sward. These new techniques, relying so heavily on a guaranteed supply of water, could not be introduced by farmers without consideration of other stakeholders. Rules limiting the unrestricted use of water to specific days were made by agreement (Bettey 1999) and legal disputes over access to rivers and streams needed to be resolved quickly and amicably in order to maintain the vital synergy between farmers, mill owners and other users.

Establishing the origin and development of the later floated water meadows or bedworks has not been without debate (Taylor et al. 2006), with sparse documentary evidence available (Cook et al. 2003). Nevertheless, by the early decades of the sixteenth century, irrigation systems were firmly a feature of the rural landscape in England. Field names with references to water meadows appear regularly, particularly, according to John Field (1993), in the chalklands of southern England. However, the earliest example that he describes, dating back to 1339 , is a reference to Le Flodgatemedewe in Minshull Vernon, Cheshire, revealing possible irrigation methods in practice at a level of sophistication pointing towards the water management systems prevailing in the seventeenth and eighteenth centuries.

According to Peter Brandon (2006), the water-meadows of the brooks that occupy the wide floodplains of the lower reaches of the Ouse of East Sussex had been inned and embanked by the early fourteenth century and formed an integral part of a sheep-corn system of farming. It is therefore conceivable that the later highly engineered floated water meadows that supported an even more intensive sheep-corn system of the eighteenth century in central southern England were a derivative of the brookland system. However, there are other possibilities.

Fussell (1955) refers to the work of Sir Anthony Fitzherbert and his Boke of Surveying and Improvements, first published in 1523. Fitzherbert recommended the diversion of streams to flood the meadows after haysel (hay harvest time) until early May, maintaining constant flow so as not to allow water to lie stagnant and all the better if the stream passed through a town so as to become enriched with sewage and seepage from middens (dung hills). The impact of the work of the Tudor landowner Rowland Vaughan in the Golden Valley of Herefordshire has been emphasised by several authors (Golden Valley Study Group 2016; Kerridge 1954; 
Taylor et al. 2006). Although not claiming he was inventor of the practice, ${ }^{i i}$ Vaughan publicised the idea of creating meadows in his book The Most Approved and Long Experienced Water Workes as early as 1610, a manuscript now considered instrumental in the development of bedwork systems in central southern England.

George Boswell's Treatise on Watering Meadows published in 1779 provides irrefutable evidence that bedwork methods of water meadow management were worthy of greater publicity. Contemporary agricultural reformers such as Arthur Young, Thomas Davis and Charles Vancouver viewed such schemes as essential to successful farming in southern England. Other publications followed by the Reverend Thomas Wright (1789) and William Smith (1806), fuelling the spread of these techniques particularly among the capital-rich agricultural improvers profiting from the high grain prices of the Napoleonic Wars. Indeed, profits from floated bedwork meadows far exceeded those of floodmeadows during this period (Bettey 1999). The idea of employing the latest irrigation techniques chimed perfectly with those fashion-conscious landed gentry who were keen to demonstrate their knowledge and showcase their wealth even though such innovations might be misplaced (Martins \& Williamson, 1994). As we shall see later, the Rother valley offered one notable landowner just such an opportunity.

Schemes of the sophistication described by Boswell could only develop where landownership of the valley was in the hands of the few and that the meadows were not subject to common rights. By the middle of the eighteenth century this had become the general case and the demise of the common meadows paralleled the gradual loss of power afforded by the manorial courts in providing the stewardship and legal framework critical for managing the meadows. Common rights of tenants were lost to landowners who were then free to fence off their land from common grazing, improve the drainage, plough up the meadow, re-seed with grasses and fully control its use (Brian 1993). Eventually the meadows were largely in private ownership and consisted of rectangular enclosures with common rights to grazing lost completely. Any resistance to the loss of the commons was attacked by agricultural reformers. Rev. Arthur Young despised commoners' rights in his characteristic forthright manner:

These are unexceptionably the most perfect nuisance that ever blasted the improvement of a country; and till they are done away, no tolerable husbandry will flourish in those districts where they are in force (Young 1813, p. 464). 
During the nineteenth century, water meadows became increasingly vulnerable to the changing agricultural economy of the late nineteenth century with the major landowners turning to artificial fertilizers and eschewing large sheep flocks that had been so essential to the arable farmers of the downlands. New types of grass and fodder crops reduced the need for hay to overwinter livestock. Water meadows required considerable day-to-day maintenance with ditches and drains needing to be cleared and sluices and hatches operated and repaired. Harvesting the hay required skilled scything as the water meadows were unable to withstand the weight of modern machinery (Bettey 1999). Such inefficiencies were made more obvious by the agricultural decline that began with the Repeal of the Corn Laws in 1846 and reached its peak during the 1870s when grain and lamb were imported cheaply from overseas and the traditional sheep/corn husbandry was largely replaced by dairy farming. With a few notable exceptions, most water meadows fell into disuse during the early part of the twentieth century with their bespoke management systems striking discordance with the rapid industrialisation of farming (Peterken, 2013).

\section{The Rother Catchment, West Sussex}

The Rother is situated at the western edge of the Weald and flows for 32 miles from its source near the village of Empshott in Hampshire to its confluence with the River Arun at Stopham in West Sussex (Figure 1). Apart from the Upper Greensand formation at its source, the Rother flows over the beds of the Lower Greensand. The Rother is unusual in having two main aquifers of very different characteristics. One consists of water from the Lower Greensand aquifer and provides the base flow of the river sufficient to maintain flow during the summer months (Environment Agency 2013). The other is calcareous emanating from the springs at the foot of the South Downs. The floodplain is of variable width; immediately downstream of Midhurst it is typically between 100 and 250 metres wide increasing to between 250 and 300 metres as it nears its confluence with the River Arun. The gradient of the river is very gentle particularly in its lower reaches, descending just 15 metres in 18 kilometres, a gradient of 1 in 116. The floodplain is overlaid with mainly fluvial sand deposits, varying in quantity throughout the course of the river. Some areas are regularly waterlogged and the river generally floods four or five times a year.

The beds of the Lower Greensand vary in their composition to such an extent that they provide both the most fertile and the most impoverished soils in the area (Jarvis et al. 1984; 
Shand et al. 2003). To the north, the fertile soils produced by the Sandgate formation of the Lower Greensand have traditionally supported good quality arable and pastoral farming. To the south, heath communities occupy areas of poor, free draining sandy soils of the Hythe and Folkestone beds in a belt parallel to the river. Towards the South Downs the soil becomes more fertile where the sandstones mix with clays of the Gault mudstones underlying the chalk downs.

Interpretation of the Domesday Book left Alan Baker in no doubt that the Rother valley with sizeable villages along the loam-rich scarp-foot zone of the South Downs and fertile alluvial plain was a prosperous agricultural area in 1086 (Baker 1973). The Rother flows by the market towns of Petersfield, Midhurst and Petworth whose growth during the Middle Ages was based on the local farming economy, cottage industries including cloth and leather, weekly markets and a position on the main trading routes from the south coast to London. The river with its tributaries became an important source of power for a number of fulling, grain and paper mills, particularly in its upper reaches above Midhurst. Despite lying on the fringe of the Wealden iron industry, the surviving hammer ponds on the tributaries flowing in from the north testify to the importance of iron working in the area from the early sixteenth to the late eighteenth centuries.

The potential of the Rother valley as a source of wealth was recognised by the aristocracy who expanded their estates from the thirteenth century onwards. The estates of Uppark, Burton, Cowdray and Petworth transformed the landscape during the eighteenth century, spearheading the piecemeal and more formal private enclosure of the land into a patchwork of hedged fields interspersed with remnants of the original woodland of the Weald left as a result of assarting, the clearing of woodland for cultivation. The process required very few parliamentary enclosure acts. Apart from the creation of the designed landscapes of the great parks, perhaps the most noteworthy individual impact came from George Wyndham, $3^{\text {rd }}$ Earl of Egremont, who invested in a scheme to make the lower Rother from Stopham to Midhurst navigable by an Act of Parliament in 1791 following the completion of the Arun Navigation in 1790. Commercial traffic on the navigation grew until the opening in 1859 of the Midhurst branch of the Mid-Sussex Railway and, following a period of use by pleasure craft, was officially closed in 1936 (Vine 1995).

Today, the Rother flows through the heart of the UK's newest national park, administered by the South Downs National Park Authority (SDNPA) since it became operational in April 
2011. It is the most intensively farmed of any of the UK's national parks, a fact that has obvious impacts on the environment, particularly its rivers. According to EU Water Framework Directive (WFD) standards, the Rother is typified by reaches of 'poor' ecological status. Despite high physiochemical indicators of ecological quality such as dissolved oxygen, ammonia and $\mathrm{pH}$, fish stocks are low and are a cause for concern (Environment Agency 2017). Degradation is thought to have resulted from both the smothering of spawning habitat by fine sediment from agricultural run-off and a lack of habitat heterogeneity as a consequence of channel modifications (Boardman et al. 2009). In addition, the banklines of the Rother channel comprise highly erodible sandy material, contributing to the high sediment yields in the Rother over a range of in-channel flows and flooding events (Plate 1) (Cox \& Soar 2017). Furthermore, fine sediment accumulation and high concentrations of suspended sediment along the lower reaches both impact on Southern Water's operations at its water abstraction site near Hardham. Southern Water is actively engaged in finding sustainable sediment management solutions for the catchment. If coupled with river restoration measures, such activities may have the potential to deliver wider ecological and economic benefits within the region.

The multiple benefits of floodplain meadows, such as water purification through the storage of pollutants and fine sediments, are widely recognised (Rothero et al. 2016). Floodplain meadow restoration on the Rother is therefore worthy of serious consideration. However, prior to this study published evidence of the previous existence of meadows is scant, a situation that would have to be addressed if wider community engagement is to be enhanced through greater historical understanding. As we shall see, the longevity of the floodplain meadows owed much to their nodal role in the agricultural cycle of the farming community and to the careful stewardship of landowners and professional land managers. Today, the Rother is perhaps an unremarkable river, worthy of only brief mentions in most guide books and academic works. Nonetheless, this study demonstrates that its significance to the local communities in the past far outweighed its physical presence and reveals a use of the floodplain that was perhaps more typical than the bedwork systems on the chalk streams of Dorset, Wiltshire and Hampshire. 


\section{Early Evidence of Common Meadows in the Rother Valley}

The earliest evidence of meadow on the floodplain of the Rother can be traced back to the Percy Chartulary, a document consisting of over eleven hundred conveyances of property that came to the Percy inheritance (Lord Leckonfield 1954). Believed to have been compiled no later than 1377, it makes several references to the purchases and exchanges of land within the parish of Petworth. During the later stages of the thirteenth century William de Percy created a great park, giving land in other parts of the manor to tenants in exchange for that he could enclose within the park, a process that marks the beginning of estate agglomeration that would continue for the next 600 years (Beckett 1984). In addition, there are several significant transactions involving specific meadows in the Rother valley, namely Budeham (Budham) meadow, Wydemede (Wide meadow), Holegatemede (Hole meadow) and Breggemede (Bridge meadow) during the late thirteenth and early fourteenth centuries.

Anthea Brian (1993, 1999) describes a system that may well have existed in the study area where the common, or Lammas meadows, were divided into strips (like the common arable fields), typically called 'doles', 'mowths' or 'lots'. The exact term used in the Rother valley is unclear but the tithe apportionments only use the term 'piece'. Each strip would be under different ownership with boundaries demarcated by wooden posts or upright stones termed 'dole stones' or 'mere stones' that were inscribed with initials, presumably of the owner. Surviving stones exist at a number of locations around the country, most notably at the Lugg Meadows, Herefordshire (Brian \& Thompson 2002), the Oxford Meads, Oxfordshire (McDonald 2007b) and Cricklade North Meadow National Nature Reserve, Wiltshire (Rothero et al. 2016; Whitehead 1981). On some meadows, each individual retained ownership of the same strip but on other meadows lots were cast each year before the hay was cut to determine who would have each strip that year. By the time that Richard Treswell completed his Great Map of Petworth in 1610, the Rother floodplain meadows had been in existence for several hundred years. Common meadows extended from west to east along the north (left) bank of the Rother as shown on the map (Figure 2) and included Upper Mead, Budham Mead, Lady Mead, Hole Mead, Mill Mead, Alderton Mead, Wide Mead, Norr Mead and Holebroke Mead. 


\section{Meadow Stewardship Evidenced through Manorial Court Records}

The survival of the meadows into the nineteenth century is testimony to the persistent attention of the manorial court to their proper management over the previous centuries. At Petworth, rights of common appendant divided the meadows into parcels or strips. These rights were attached to particular tenements with restrictions on the type of livestock that were permitted to graze on the common meadows of Upper, Budham, Bridge, Hole, Mill Wide, and Holebroke meads (Lord Leckonfield 1954). Cattle and sheep were allowed to graze but animals that might damage the meadows such as geese, goats and pigs were not. Horses that were used for transport were also prohibited but exempt if used for ploughing. Enforcement of these regulations was administered through the manorial court and rested on the diligence of either the messor or hayward in carrying out their duties as superintendents of the meadows. As is usual with court records, we learn a great deal about responsibilities and regulations ironically through what people failed to do. William Stutt, who was Messor from 1600 to 1602 , so neglected his duties as supervisor of the commons and meadows that he suffered an amercement of $2 \mathrm{~s} 2 \mathrm{~d}$ in October 1601. In the following March he was ordered to pay a further $3 \mathrm{~s} 4 \mathrm{~d}$ for not superintending Wide and Budham meadows and allowing pigs and transport animals to graze on them. Finally, he was fined another shilling in October for permitting access to Wide meadow for horses and other transport animals (Lord Leckonfield, 1954).

Tenants and owners of strips were obliged to attend a 'setting out' day as the demarcating stones and posts were often hidden by the full-grown hay and additional posts and bits of rag were used to locate them (Brian 1999). Critically, each owner was responsible for his own stones or posts and for fencing animals out of the meadow typically during February. The amercement of tenants for transgression of local rules governing management of the meadows was a fairly regular occurrence. At Petworth, several portions within the meadows were annually demarcated by the tenants. In July 1641, the tenants of Upper Mead were ordered to perform this duty within six days or face a penalty of 5s. In September they were commanded to repair the fences and clean out the ditches, the penalty being doubled. A year later they had to be reminded again and the amercement was increased to 40s. In 1644 it was 50 s. Such inaction, though, was at odds with the more exemplary tenants of Budham Mead who had responded promptly to the first order (Lord Leckonfield 1954). 


\section{Landscape Improvements into the nineteenth century: The $3^{\text {rd }}$ Earl of Egremont and the Rother Navigation}

George O'Brien Wyndham, the $3^{\text {rd }}$ Earl of Egremont, had a reputation as an enthusiastic agricultural improver and devoted much of his energy to making his estates more productive through cattle breeding, crop experimentation and major water transport, drainage and irrigation schemes. In addition, he spent $£ 350,000$ acquiring over 12,500 acres of freehold land in Sussex and a further $£ 50,000$ in West Sussex converting copyhold into freehold land (Wyndham 1950). The Reverend Arthur Young, ${ }^{\text {iv }}$ a frequent guest at Petworth, eulogises the Earl at almost every opportunity in his General View of the Agriculture of the County of Sussex (1813). Large tracts of Egremont's estate were brought into production by this 'animated and enlightened improver' (Young 1813, p. 188). The stag park was cleared by the Earl in about 1800 and transformed into a model farm for agricultural experimentation (The National Trust 1997) and effective drainage and watering of meadows were recognised by Egremont as critical ingredients to his land improvement project. ${ }^{v}$ Young describes five or six acres of the park being irrigated by water flowing from the artificial lake constructed during the landscaping of the park by 'Capability' Brown. The herbage of the irrigated part of the park was 'too clearly improved to admit any doubt of its effects' (Young 1813, p. 225). ${ }^{\mathrm{vi}}$

The likelihood of improvement to the floodplain meadows was given an unlikely boost by the commencement of Egremont's most ambitious project - the Rother Navigation. Impelled by the recent success of the Duke of Bridgwater's canal to transport coal from his mines at Worsley to the industrial areas of Manchester, the Earl now sought to benefit by similar means (Vine 1995). Following an Act of Parliament passed in 1791, the Rother Navigation was completed in 1795 and ran a distance of 11.3 miles from Stopham to Midhurst with eight locks and a rise of just 46 feet. ${ }^{\text {vii }}$ The physical impact of the scheme on the valley was reduced by the adoption of the course of the river as the main navigable waterway with a minimum of new cuts being created due to the gradual fall of water and consequently the gentle flow prevailing for most of the year. Documented estimates for the works included new cuts, locks, sluices for discharging flood water, bridges over the locks, widening and clearing the existing channel, creating passing places, new flood gates, altering existing bridges, gates at fences and small bridges for the towing path. ${ }^{\text {vii }}$ Indeed, Arthur Young viewed the regulation of water flow to be a positive benefit: 
The superiority of the canal over a river, for navigation, consists in it not being so subject to the violence of inundations and torrents; but this enemy has in the Rother been converted into a friend, for the drains can be opened at will, and all the adjoining meadowland irrigated to the great benefit of the proprietors, which is done by stopping the drains (Young 1813, p. 424-425).

Young claimed that 'more than 100 acres of contiguous meadow have been highly improved by these new drains' (p. 195). ${ }^{\text {ix }}$ Indeed, he proclaimed that the meadows were 'now converted into a fine water-meadow, and worth full $£ 3$ per acre’. He continues with a description of how the meadows were watered:

These grounds are at any time capable of being flowed by the means of sluices made through the towing-path, which acts as an embankment; and in summer, if the river is too low, by fresh streams which flow into it from the upper grounds; and the water can at pleasure be drawn off by drains into the lower level below the locks, and sometimes, where particular circumstances render it necessary, by the means of culverts carried across the bottom of the river (Young 1813, p. 195).

A plan of water meadows drained between 1794 and 1796 reveals sluices which if shut down will make the water flow over Hole Meadow, Rough Piece, and Pike Shoot in a few hours in the driest season' (Figure 3). ${ }^{\mathrm{x}}$ Such a system is akin to the floating upwards method mentioned earlier and, though relatively unsophisticated, would have been an effective way of converting drains into carriers during dry spells of the spring and summer months. Use of the existing river for the navigation may have had a positive impact on the majority of the surrounding meadows, but there were still complaints about damage caused to them. Damage to the meadows at Sutton is documented ${ }^{\mathrm{xi}}$ and there is protracted correspondence between Charles Biddulph of Burton Park and Lord Egremont concerning a faulty culvert that regularly flooded four acres of Bidduph's Merrifield meadow. ${ }^{\text {xii }}$ Drainage was also a problem on Lord Egremont's own land. Budham meadow required the digging of a new drain. After several unsuccessful attempts at draining the boggy meadow, Lord Egremont laid a wooden pipe across the bed of the river to discharge onto the opposite floodplain and drain back into the river at the mill head.

A number of factors may have counted against the creation of grander schemes, one of them being the survival of common meadows along the floodplain. As observed on the tithe maps 
of the $1840 \mathrm{~s}$, large areas of the floodplain were common meadows, a situation that was even more striking on the plans of the Rother Navigation of 1797 . The plans, one a draft and the other a fair drawing, identify those stretches of the river that were filled and newly cut as well as the location of locks and bridges (Figure 4). ${ }^{\text {xiii }}$ Both plans state the names of common fields together with their owners and occupants, thus providing invaluable evidence of common meadow survival in the late eighteenth century. From Easebourne to Stopham the plan of the Rother Navigation lists 31 common meadows with 186 individual owners (Table 1 and Figure 5). Those common meadows with relatively large numbers of owners were at Easebourne (13 owners), Upper Common Meadow (11), Sutton Common Meadow (13), Coates Common Meadow (13) and Waltham Common Meadow (11). The draft plan appears to show small posts in the common meadows to demarcate ownership of the various portions of meadow indicative of the continuing importance of the meadows to local communities.

Lord Egremont was an entrepreneur and a visionary who recognised that by adopting an integrated approach to planning and implementation of the improvement works he would be able to deliver wide-ranging benefits for his estate, his labourers, local communities and the regional economy. Ultimately, the success of the Rother Navigation and meadow improvements rested on an understanding of the river-floodplain hydrology, river flow hydraulics and an enthusiasm for drainage engineering systems. Conceivably, these experiences and proficiencies would have developed gradually over time as floodplain works were implemented somewhat on a trial-and-error basis, coupled with a steadfast commitment to adaptively managing the schemes over time and act on any unforeseen outcomes. While environmental sustainability might not have been a priority, in adopting an integrated 'catchment-based' approach and ensuring that improvements were delivered through effective and innovative interventions, while optimising multiple benefits to a range of stakeholders, Lord Egremont's assumed responsibilities align closely to the duties of the 'catchment coordinator' in today's Environment Agency. It is of no surprise, then, that William Marshall in his study of The Rural Economy of the Southern Counties, published in 1798, gave considerable praise to the Earl 'whose patriotism and benevolence flow in every direction' (p.153). Marshall declared:

Lord Egremont is carrying on the patriot work of improvement, with unequalled zeal; and on a broader basis, than that on which it has, heretofore, been pursued, in any part of the Island (Marshall 1798, p. 195-196). 


\section{Early Nineteenth Century Maps and Plans of the Rother Floodplain Meadows}

In addition to the maps accompanying the Rother Navigation, clear evidence of the complex pattern of meadow ownership is provided by the detailed plans of several common meadows contained in the Cowdray and Petworth estate records. The major landowners were clearly keen to map the intricate pattern of plots and then set about rationalising and consolidating the strips into larger, more rectangular blocks. According to text on the various plans, the method of identifying the boundaries of the strips was done by the owners and occupiers pointing out their 'pieces' during the actual survey. On behalf of the Earl of Egremont, surveys by his estate manager Thomas Upton of the common meadows known as Sutton, North, and Byworth were all conducted during 1807 using this method. ${ }^{\text {xiv }}$ These plans were clearly precursors to new arrangements that would be drawn up by agreement between the various landowners as the plan of Sutton, though originally drawn in 1807, shows the later layout superimposed upon it (Figure 6). The new arrangements for land ownership for North Common Meadow and Upper Common Meadow were also completed by Thomas Upton in $1817 .^{\mathrm{xv}}$

More detailed and revealing surveys of the Cowdray Estate were completed by William Barlow on behalf of William Poyntz between 1813 and 1814. His 1813 plan of Ambersham Common Meadow ${ }^{\mathrm{xvi}}$ details the ownership and precise location of the strips together with a list of owners and the rotation of their rights to the herbage of the meadow, a system that is regarded as having superseded the lot-drawing method of the open field system (Brian 1999). The list identifies those individuals whose ownership does not change, distinguished by the use of colour on the plan (Figure 7). However, much of the meadow appears to record partnerships in a changeable acres system of rotation (Baker \& Butlin 1973; Sylvester 1958), whereby pairs of individuals claim the rights to the herbage of the same plot in alternate years or where plots of meadow are exchanged annually between individuals. This rather complex arrangement is no doubt a legacy of the medieval open field system. Despite piecemeal consolidation of land ownership in the meadows, 5.6 acres of the 19.1 acres of Ambersham Meadow were exchanged annually between pairs of landowners with a further 1.2 acres claimed by pairs of individuals in alternate years. The quantity of land exchanged between individuals was almost precisely equal. For example, Mr William Poyntz Esq. of the Cowdray Estate, the major landowner in the parish, exchanged just over an acre of meadow with Mr William Dennett every year. Both landowners exchanged 5 plots each, comprising 
1.04 acres for Mr Poyntz and 1.08 acres for Mr Dennett. Strips varied in size from 7 perches to as much as 2.5 acres, although the more typical size being between 20 and 30 perches. The plans also depict what appear to be posts setting out the limits and alignments of each plot, similar to those shown on the Rother Navigation draft map described above. The posts do not always mark the true extent of the plot but simply positions through which a straight line could be drawn that when projected would terminate at the river bank.

The process of consolidation of the floodplain meadows is illustrated by an 1814 plan of Ambersham Meadow (Figure 8). ${ }^{\text {xvii }}$ We may assume that the symbols on the map represent the wooden or stone boundary posts set out in the meadow with the same initials inscribed on the appropriate side of the post. ${ }^{\text {xiii }}$ Whether these posts were temporary or permanent is unclear, however field work discovered two large dressed 'dole' stones in the nearby parish of Coates which, remarkably, still bear the initials of the owners of land to the left and right of the posts (Figure 9). Whilst no date can be reliably attached to these stones, their size and freshness suggest that they may be remnants of the meadow consolidation process of the first half of the nineteenth century. Ordnance Survey six-inch maps (Second Revision) published in 1914 depict 'stones' in Byworth, Umbley and Puphill meadows. The total acreage for each landowner in Ambersham Meadow remains very close to that recorded in the earlier plan of the strips, the major change being the larger individual plots. The orientation of the boundaries also remains the same. Further evidence of land consolidation is contained in a similar map of Umbley Meadow dated 1814. ${ }^{\text {xix }}$ Here, it is clear that William Poyntz exchanged a set of meadow strips for others sited in Easebourne, the parish of his own Cowdray Estate.

\section{The Meadows of the Rother Valley as revealed in Tithe Surveys}

Most landscape historians will no doubt be familiar with the maps, apportionments and accompanying tithe files for which there are detailed descriptions available (Evans 1976, 1997; Kain et al. 1995; Kain \& Prince 1985, 2000; Vamplew 1981). The work was carried out with typical Victorian efficiency to produce the high-water mark in the cartographic representation of many parishes before 1850 (Harley 1972; Kain \& Prince 2000) and indeed the most comprehensive record of the agrarian landscape of any period (Prince 1959).

For each individual field the apportionment lists its number, owner, occupier, name and description, state of cultivation, acreage, and tithe rent charge. Today we would substitute the 
term 'state of cultivation' with 'land use'. Examination of the land use is made difficult by the broad definitions provided by the Commission to the tithe surveyors and also the subsequent variations in their interpretation of them. The definition of 'arable' and 'pasture' varied around the country and as Kain and Prince (1985) comment:

\section{Although what tithe valuers recorded as arable may not have been what modern surveyors would record as arable, we may be fairly sure that it was what local contemporaries would have understood by the term (p. 140).}

The treatment of grassland is similarly inconsistent with sub-types differentiated in some apportionments but not in others. In the parish of Coates, to the southeast of Petworth, the location of meadow is unequivocal with, for example, the state of cultivation of one particular field stated as 'meadow' and a name and description entry that reads 'One Piece in Coates Meadow South Side of Ditch'. ${ }^{x x}$ A neighbouring field, however, lies in the parish of Bury where all pasture and meadows are classed unhelpfully as 'grass'. Here we can turn to the name and description which states for this particular field the name 'Trip Meadow'. Meadows tended to be rather more permanent features in the landscape, commanding higher values, protected status and, as a consequence, recognition through field name longevity (Rackham 1986). In practice, therefore, the names of fields and state of cultivation are best used in combination to confirm land use.

On occasions, the name and description suggest a land use that is at odds with that recorded as the state of cultivation. According to some interpretations, such differences can indicate conversion of fields to other land use types, and vice versa, a feature that is particularly pertinent to meadows (Peterken 2013). However, mismatches between field names and land use could be attributed to the valuers' interpretations in agreement with the landowners. The danger here is that we cannot assume that a different state of cultivation to the name and description necessarily means a change of land use, simply interpretation. The tithe files that accompany the tithe surveys provide an important supplement to the maps and apportionments and can reveal greater detail about the nature of local agricultural practices (Cox \& Dittmer 1965; Kain \& Holt 1983).

The tithe surveys reveal that some 1,198 acres of meadow once occupied the floodplain of the Rother between Midhurst and its confluence with the Arun at Stopham (Figure 10). The assistant tithe commissioner for Petworth reported there to be "very rich flat meadow by the 
River, part of which are low and wet' and 'liable to be flooded'. ${ }^{x i}$ The richness of the meadow grasses is reported elsewhere in the tithe files, for example at Sutton. An important legacy of the territorial arrangements of their ancestors was that as many as twenty one parishes along the $11 \frac{1}{2}$ miles of the Rother from Midhurst to Hardham had a share of the floodplain meadows. Parishes further down the river enjoyed the benefits of meadows on a floodplain of increasing width, with Tillington (180 acres), Petworth (171 acres), Fittleworth (168 acres) and Stopham (105 acres) possessing some 21 per cent of the total floodplain meadows. Previous expansion of the Petworth Estate beyond its parish boundary through engrossment and emparkation (Kerridge 1969) ensured that of the 70 owners, George Wyndham (later created Baron Leconfield in 1859), owned the lion's share with nearly 35 per cent (461 acres) of the floodplain meadows. ${ }^{x x i i}$

When we consider the pattern of land occupancy based on the tithe surveys, several areas of floodplain meadows reveal the familiar strip pattern associated with the common field system of farming. Significant remnants of common meadows survive in the parish of Fittleworth (Lee, Mill and Wide meadows) and upstream in the parish of Petworth (Byworth, Sweet and Wide meadows). However, the clearest example of common meadow in the 1840s is in the parish of Coates where multiple strips of intermixed occupancy remain in Steeple, Hesworth and Coates meadows (Figure 11). The accompanying tithe file for the parish of Coates makes reference to the common meadows containing over 47 acres which were exempt from tithe payments by reason of pieces of land in the meadows having been 'at a distant period' allotted to the rector in lieu of the tithes. At Fittleworth, the 30 acres of Lee, Mill and Wide meadows were also exempt perhaps for similar reasons. ${ }^{\text {xiii }}$ Repeated use of the term 'piece' in the 'Name and Description' column of the tithe apportionment clearly suggests that at least 216 acres of floodplain meadow remained in severalty by the mid-1840s. Four of these pieces are referred to as 'changeable', suggesting that rotation of ownership survived in a few places.

Figure 12 demonstrates how central the common meadows were to the local farming community. According to the tithe surveys, the strips in the parish of Coates, though lying entirely within the parish, were occupied by farmers who worked on the land not only in Coates but also the surrounding parishes of Bury and Fittleworth. Coates offered wide floodplain meadows but had a relatively small population, perhaps unable to exploit the rich harvest of hay that such a location would offer. The nodal function played by the meadow 
would have been limited were it not for the bridge at Fittleworth that provided access to farmers north of the river. Conceivably, transport of the hay could have been by river to the bridge then by road into the parishes of Fittleworth and Egdean. Tracks from the hamlet of Coates to the meadow are evident on the tithe map. The division of the strips within the meadows intriguingly follows a broad pattern. Farmers from Fittleworth occupy strips by the river principally in the northern half of the meadow whilst those from Bury and Coates occupy strips in the south and west of the meadow, somewhat mirroring the surrounding geography. Such an arrangement would have limited any drawing of lots by farmers from neighbouring parishes to specific sections of the meadow.

By the 1840s the tithe surveys illustrate how dominant the larger landowners had become even in areas where strips survived. Out of the 45.5 acres comprising Coates and Hesworth meadows, 82 per cent were owned by landowners of at least 20 acres of farmland and 61 per cent were owned by farmers with over 100 acres of farmland including George Wyndham.

\section{Anatomy of the meadow water management system}

Along the Rother valley, the water management system of each meadow would have been controlled by the topography and conditioned by the hydrological regime, but with success contingent on the skilled regulation of water flow by the experienced 'drowners', 'watermen' or 'meadmen' who operated the hatches and sluices - the asset managers of the day. ${ }^{\text {xxiv }}$ By utilising the topography to steer water over the meadow, the drowners used water wisely in an attempt to optimise the frequency and spatial distribution of wetting over subareas of meadow at different times and thus maximise productivity. By utilising gravity-driven drainage, the floodplain was a machine that could expend energy in performing hydrological work and so the lie of the land was thus critical to defining the anatomy of the meadow system. These were not nascent approaches but highly developed drainage systems, finetuned over time to improve function and optimise benefits. Each water management system was therefore unique.

Lord Egremont's canalisation of the main river would have altered the water management system significantly. In the Rother valley, the stretch of meadows including Coates, Steeple and Hesworth provide an excellent illustration of the various components of the water management system (Figure 13). Here, LiDAR data present an opportunity to explore this system by displaying ground elevations at high resolution and revealing topographic features 
that would not be readily discernible in the field. Any reconstruction of the water management of the floodplain meadows based on field evidence alone would be severely limited by the continual change that the site would have undergone over the 170 or so years since the tithe surveys. Ditches would have been re-dug, the meadows levelled and ploughed at some point and material periodically dumped when the Rother was dredged. Virtually all the meadows are subject to winter flooding and therefore receive regular deposits from the river which further obscure the remains. The channels dug to distribute water through the meadows, as shown on James Crow's plan of $1779,{ }^{\mathrm{xxv}}$ are still evident in the imagery. Here, a sluice may have controlled the water flow from the river and the name of the meadow on the opposite bank ('Weyre Mead') hints at more sophisticated water management than simple natural flooding.

The Coates complex of meadows appears to comprise a hierarchical arrangement of drainage channels that relates very closely to the variation in ground elevations across the floodplain. For each meadow, the river forms one boundary whilst ditches or watercourses form the other boundaries, all of which are artificial. The Rother channel (large arrows) provided the primary source of surface water to the area but only if flow events were of high enough magnitude to exceed the invert level of sluices sited along the river's course. The positioning, elevation and operation of the sluices and hatches would have been critical to the periodic large scale inundation of the meadows that would have also provided a surge of new nutrients into the floodplain. Water from the Rother would have been carried onto the meadow by a series of feeder channels, typically emanating perpendicular to the Rother channel and often circumscribing individual meadows, where gradual wetting of the contiguous areas would have occurred through smaller channels and seepage. The recharge of soil moisture and groundwater beneath the floodplain during periods of flooding, controlled wetting and periods of sustained local precipitation would have afforded some mitigation against damage to establishing meadow grass during drier conditions.

The ability of water to be carried away from the main Rother channel under gravity is made possible due to the bankside area of the Rother typically being at a higher elevation than the back of the floodplain due to a history of overbank sedimentation and potentially related to the construction of the Rother Navigation (Cox and Soar 2017). This inverted floodplain topography can be seen in a cross section through the valley (inset Figure 13) and would have been exploited for not only facilitating the wetting of the meadow but in ensuring that once 
wetted, the meadow could be drained efficiently to avoid long periods of oversaturation or standing water. Patches of dendritic drainage patterns (branched forms resembling veins of a leaf) can be seen in between the feeder channels and demarcate preferential flow lines directing water towards points of confluence with larger drains or the back drain, further demonstrating the inverted drainage effect. The back drain conveyed water collected at the back of the floodplain to rejoin the Rother further downstream but also would have diverted water via a series of hatches back onto the meadow at desired locations. In addition, the back drain would have intercepted water fed, much like a catchwork system, from tributaries and springs, thus enabling a near continuous supply even during periods of low water level in the Rother.

On the left floodplain (facing downstream), Figure 13 suggests a drainage pattern perhaps more akin to a bedworks system, with a carrier channel intercepting water from a tributary and overland flow, with perpendicular secondary channels delivering water to the meadow conceivably through a series of hatches or when overtopped before collecting in a bottom drain. Here, though, the carrier appears to be a carrier-drain hybrid as when not blocked at the end, water would gradually be directed under gravity to where the carrier itself joins the drain. It is plausible that this carrier-drain and associated secondary channels were implemented to enable expansion of the meadow onto more elevated land at the back of the floodplain, however this would have been unfeasible on the right floodplain due to the steeper valley wall behind the back drain (as revealed in the cross section, see insert Figure 13).

The survival of two dole stones described above adds further justification for examining the site more closely with half an eye on the possible re-instatement of meadows at some point in the future as a component of a broader floodplain restoration scheme along the lower Rother valley. The analysis of LiDAR data has enabled the anatomy of the historical water management system to be brought into sharper focus, with plausible locations of flood gates, and at least a schematised depiction of the drainage systems providing an initial design guide for restoration.

\section{Implications for floodplain restoration}

How we utilise, manage and value land today is very different to that of nineteenth century farming communities. Since the 1970 s, a shifting policy framework has increasingly placed 
emphasis on farming the land 'responsibly' and coupling production with other payment schemes where land area and environmental schemes are assigned economic value, or 'natural capital'. Efforts to improve productivity through intensification and extensification of farming must be appeased with a recognised duty to conserve and enhance attributes of the natural environment and a perception of 'place' as a rich ensemble of qualities that impact on our wellbeing. While contemporary land management now places 'environment' at the heart of policy, its sustainable implementation rests on balancing and optimising the interests of multiple bodies which, along the valley floor, means resolving conflicts between users of the floodplain as a resource. A strategic and collaborative approach is critical to enable environmentally responsible farming to be delivered as a component of integrated river basin development. Initiatives that call for better holistic and sustainable use of the floodplain are central to this. Nationwide programmes such as 'Making Space for Water' (Defra 2004), 'Natural Flood Management' (Environment Agency 2014) and 'Making Space for Nature' (Lawton et al. 2010) provide the context for 'Catchment Sensitive Farming' (Natural England in partnership with the Environment Agency and Defra 2014) and a 'catchment-based approach' (Defra 2013) to environmental management, sustainable farming and enhancing river environments. In practice, this will mean improving water management and sediment transfer at the catchment scale, enhancing the connectivity of spaces for wildlife along river corridors and realising the diverse benefits within floodplains by restoring natural riverine processes (Kondolf et al. 2006). These measures, combined with safeguarding against soil loss and promotion of payments for ecosystems services, may go some way towards achieving a restored and sustainable landscape.

Perhaps we are now poised to see a renaissance in historical farming practices that place far fewer demands on nature and, steered by environment stewardship funding schemes, where the multiple benefits are self-evident to the farming community. However, despite universal good intent, turning guiding visions and principles into practice is highly problematic. Vast policy silos congest a legislative framework that transcends regional, national and European levels of control and regulation and, therefore, it is bureaucracy that is the greatest source of inertia to land improvement on a scale and complexity that did not exist when Lord Egremont enacted his grand schemes. Over the coming decades, the transposition of European laws to UK jurisdiction will no doubt provide further challenges to realising the sustainable land management agenda while ensuring the agricultural sector remains a vibrant and competitive industry within Europe. 
In the near term, the prospect of delivering sustainable land management and restoration improvements rests with regional bodies who will implement measures that address local policies with inconsistent understanding of the interactions between catchment systems, local communities and individual citizens (for example, see South Downs National Park Authority 2013). In the context of sustainable farming, 'making space for nature' presents an opportunity to appreciate the cultural heritage value of landscapes and recognise the wider benefits of the rural idyll and the bespoke qualities of farmed landscapes that arguably have been blurred in the drive to meet minimum standards imposed by EU legislation. The 'Living Landscapes' programme of the Wildlife Trusts (Wildlife Trusts 2017) is a good example of environmental restoration initiatives that showcase the rich 'value-added' benefits of openly accessible re-naturalised landscapes on wellbeing and wildlife. Similarly, the 'Water Friendly Farming' project of the Freshwater Habitats Trust (Biggs et al. 2014) aims to promote the implementation of a varied, but interlinked, ensemble of management measures aimed at balancing farming with habitat provision within the specific catchment context. These schemes place 'people' and 'collaboration' as the catalyst for delivery, including the uptake and participation of farmers, local groups and individuals. It is no surprise that in setting and delivering River Basin Management Plans, Defra's catchment-based approach places collaboration as a central pillar in the process, whereby local decision making and consultation through catchment partnerships at local scales influence the broader regional plans. The catchment approach, therefore, can be an effective mechanism to address local issues in meeting national and European legislation, such as the Water Framework Directive (WFD) of the European Union. Aligned to this, it is no longer acceptable for regional water companies to deliver their services without considering the sustainability of the range of activities that impact on water. In the Rother catchment, collaborating with stakeholders to implement best practice catchment management, adaptively, and deliver ecosystem services is now the foundation of Southern Water's 'Integrated Water Cycle Management' scheme (Southern Water 2017).

Restoration of floodplain meadows along the lower Rother valley would strike a chord with the ethos and impetus of integrated catchment management and catchment sensitive farming, while engaging fully with regional agencies, landowners, local communities and visitors in their design, implementation, maintenance, stewardship, and enjoyment. The plethora of benefits to biodiversity, soil conservation, flood risk management, cultural heritage and wellbeing are well documented (Rothero et al. 2016) and thus wet meadow provides a means 
to leverage a rich source of 'natural' and 'social' capital to compliment and offset productivity from arable and pastoral farming. Realising these benefits fully, though, requires restoring meadows where they once flourished and where they can be identified as most likely to benefit from the prevailing environmental controls and conditions. Accessibility to these sites would be a critical precursor to any scheme if floodplain meadows are to impact on community wealth and enable our re-enchantment with the Rother meadows to be fulfilled. The 'Coronation Meadows Project' (Coronation Meadows 2017) encapsulates this in its drive to celebrate the heritage of meadows within the UK, establish new meadows and encouraging people to discover their many benefits. The Countryside Stewardship Scheme (CSS) in England provides incentives to farmers and land managers for engaging in activities such as habitat conservation, flood risk management, reducing pollution from agriculture and preserving heritage features of the rural landscape. This is a competitive agrienvironment scheme administered by Natural England, the Forestry Commission and the Rural Payments Agency on behalf of Defra (Natural England, 2017) and provides a vehicle for enabling lowland meadow creation and restoration. In reconstructing the wet meadows along the Rother, here, there is now an opportunity perhaps to put forward a scheme that would serve as a demonstration site. Building on the evidence assimilated, the feasibility of such a scheme would require mapping of meadow opportunity areas and this remains a near term impetus for further research.

Meadow re-establishment would best be achieved as a component of a suite of integrated measures focusing on floodplain rehabilitation and improved connectivity between the river channel and the floodplain, hydrologically, geomorphologically through sediment exchange and ecologically (Cox \& Soar 2017). Reinstating 'functional' floodplains is a firmly established approach to the practice of river restoration and fully embraces the wider 'making space for nature' concept by realising opportunities for reversion of farmland, re-wilding, floodplain woodlands, wetlands, riparian fringe extension, etc., while contributing to wider objectives of regional sediment and flood risk management.

\section{Conclusion}

The tithe surveys of the 1840 s capture the intricate structure of land use and, to a degree, the functioning of farming practice at a pivotal time for the floodplain meadows of the Rother valley - a picture of an improved meadow system and even an exemplar of meadow 
management to showcase to other regions. Evidence from the maps and plans cited above demonstrates that common meadows occupied the floodplain of the Rother in all the parishes through which the Rother flowed from Midhurst to its confluence with the Arun. There is clear evidence that the meadows were organised along lines similar to that of the arable open fields and held a high value due to the richness of the land for pasture and to the high yield of its hay. Their importance and value helped them to resist enclosure and as we have witnessed, enclosure was relatively slow and piecemeal. By the mid-nineteenth century, lot casting had clearly ceased in the Rother valley and the strips had come into private ownership with some remaining as 'changeable land'. Common grazing rights remained over the whole of some of the meadows from Lammas to Candlemas. The strips were marked permanently by the owners with their own dole or mere stones carrying the owners' initials. The use of changeable land may mark a stage in the process of change from lot casting to permanently enclosed fields. Once ownership had become permanent, the exchange of strips became desirable and the removal of common grazing rights inevitable.

The traditional meadows embodied the symbiotic relation between communities and their land, each with their own uniqueness in landscape and farming, and a longevity safeguarded via the stewardship of enlightened landowners and governance under the manorial court system. The meadows presented a way of life as much as a way of farming, bestowing a sense of belonging and place and, conceivably, satisfactory wellbeing. Arguably, endurance of the lower Rother meadows, and their organic improvements, relied primarily on the actions of Lord Egremont and the amicable cooperation and agreement between the users of the floodplain and secondarily on the physical factors that ensured the frequent wetting of the floodplain. These cherished values of community, sense of place, amicable cooperation and stewardship prevailed from provenance to prominence in the 1840 s but inevitably were unfortunate casualties of the demise of the meadows associated with intensification of farming during the second half of the nineteenth century and have been forsaken as much as the fields themselves have become forgotten.

This paper has presented a blended approach to unravelling the story of the floodplain meadows in the Rother valley. A rich narrative has been discerned by merging chronological archival evidence with a retrogressive perspective gleaned by scrutinising field and remotely sensed information, and this approach holds considerable potential for being replicated at other sites. Conceivably, the evidence here suggests that while the form, features and 
functioning of the meadowlands were dictated by the physical geography of the Rother valley, the fabric of the floodplain meadows rested very much on a bespoke social geography characterised by the complex relationships between land regulators, owners, occupiers and workers. If we are to consider the future of the floodplain and contemplate landscape restoration, then the historical treatment here serves as a vital knowledge base for understanding the traditional system of meadow creation, operation and management and the manifold relations people had with their local environment (Antrop 2005). Hope for the reenchantment of the wet meadows as an indispensable component of river floodplains relies critically on historical evidence, community engagement and tacit knowledges and not solely on state of science restoration methods.

Overall, re-establishing floodplain meadows in the lower Rother valley presents an opportunity to reconnect communities to their landscape, to engage communities in the use of the land and for communities to benefit directly from the landscape, while enabling the practice, provision and participation in environmental sensitive farming on the Rother floodplain as part of a wider landscape restoration programme. In reconstructing the wet meadows along the Rother, we believe there is considerable prospect for designing and implementing a scheme that would serve as a demonstration site. The application of LiDAR data, coupled with hydrological modelling tools, has provided valuable insights (subject to a degree of speculation) into the water management system of the lower Rother meadowlands and delivered a tentative blueprint for meadow restoration. Such an approach has clear potential for transfer to other sites. In many ways, such efforts would provide a realistic prospect for rekindling the sense of uniqueness of place so embodied in the complex interrelationships between the farming communities and the landscape at the time of the tithe surveys, but now cognisant of the immense additional benefits of floodplain meadows to biodiversity and wellbeing.

\section{Acknowledgments}

We would like to thank the South Downs National Park Authority (SDNPA) and the National Trust for their financial support and encouragement. In addition, we are most grateful to Lord Egremont for allowing us to study and reproduce material from the Petworth Archives and to the staff of West Sussex County Record Office for their tireless efforts to find archival material and for permitting us to use the scanned images of the tithe maps. We also thank 
Jennifer Cox for liaising with the various estates, undertaking field work and providing numerous leads throughout the study and acknowledge Kathy Stearne, Chryssa Brown, Catherine Hudson and Samuel Pitman for their help in the field and numerous undergraduate students at the University of Portsmouth who toiled over the digitizing of the tithe maps. Special thanks is given to Andrew Thompson of the Petworth Estate for providing access and transport during field work. Finally, the authors are grateful to the editor and the referees for their very helpful comments and suggestions. 


\section{References}

Antrop, M., 2005. 'Why landscapes of the past are important for the future'. Landscape and Urban Planning, 70(1-2), pp. 21-34.

Baker, A. R., 1973. 'Field systems of Southeast England'. In A. R. Baker \& R. A. Butlin, eds., Studies of Field Systems in the British Isles. Cambridge University Press, pp. 377-429.

Baker, A. R., \& Butlin, R. A., 1973. Studies of field systems in the British Isles. Cambridge University Press.

Beckett, J. V., 1984. 'The pattern of landownership in England and Wales, 1660-1880'. Economic History Review, 37(1), pp. 1-22.

Bettey, J., 1999. 'The development of water meadows in the southern counties'. In H. Cook \& T. Williamson, eds., Water management in the English Landscape. Field, marsh and meadow. Edinburgh University Press, pp. 179-195.

Bettey, J., 2003. 'The development of water meadows on the Salisbury Avon, 1665-1690'. Agricultural History Review, 51(2), pp. 163-172.

Bettey, J., 2007. 'The floated water meadows of Wessex: A triumph of English agriculture'. In H. Cook \& T. Williamson, eds., Water meadows: History, ecology and conservation. Macclesfield: Windgather Press, pp. 8-21.

Biggs, J., et al., 2014. Water friendly farming. Results and practical implications of the first 3 years of the programme. Oxford and Fordingbridge: Freshwater Habitats Trust \& Game and Wildlife Conservation.

Boardman, J., et al., 2009. 'Soil erosion and risk-assessment for on-and off-farm impacts: A test case using the Midhurst area, West Sussex, UK'. Journal of Environmental Management, 90(8), pp. 2578-2588.

Boswell, G., 1779. A Treatise on Watering Meadows. Wherein are Shewn some of the Many Advantages Arising from that Mode of Practice, Particularly on Coarse, Boggy, or Barren Lands. London: Almon.

Bowie, G., 1987. 'Watermeadows in Wessex: A re-evaluation for the period 1640-1850'. Agricultural History Review, 35(2), pp. 151-158.

Brandon, P., 2006. The South Downs. Chichester: Phillimore.

Brian, A., 1993. 'Lammas Meadows'. Landscape History, 15(1), pp. 57-69.

Brian, A., 1999. 'The allocation of strips in lammas meadows by the casting of lots'. Landscape History, 21(1), pp. 43-58.

Brian, A., \& Thompson, P., 2002. The history and natural history of Lugg Meadow. Herefordshire: Logaston Press. 
Cook, H., \& Cutting, R., 2008. 'The Harnham Water Meadows Trust: Complex management for a heritage landscape by the voluntary sector'. Journal of Farm Management, 13(5), pp. 24-31.

Cook, H., et al., 2004. 'Productivity and soil nutrient relations of bedwork watermeadows in southern England'. Agriculture, ecosystems \& environment, 102(1), pp. 61-79.

Cook, H., Stearne, K., \& Williamson, T., 2003. 'The origins of water meadows in England'. Agricultural History Review, 51(2), pp. 155-162.

Cook, H., \& Williamson, T. (Eds.), 2007. Water meadows: History, ecology and conservation. Macclesfield: Windgather Press.

Coronation Meadows, 2017. Retrieved May, 2017, from

http://coronationmeadows.org.uk/about

Cox, E., \& Dittmer, B., 1965. 'The tithe files of the mid-nineteenth century'. Agricultural History Review, 13(1), pp. 1-16.

Cox, J. R., \& Soar, P. J., 2017. Accounting for sediment transfer along the River Rother, West Sussex. Final Report. University of Portsmouth.

Cummings, I., 2007. 'The effects of floating on plant communities'. The Research and Development Bulletin, 5(2), pp. 53-60.

Cutting, R., \& Cummings, I., 1999. 'Water meadows: Their form, ecology and plant ecology'. In H. Cook \& T. Williamson, eds., Water Management in the English Landscape. Edinburgh University Press, pp. 157-179.

Davis, T., 1811. General View of the Agriculture of Wiltshire: Drawn Up and Published by Order of the Board of Agriculture and Internal Improvement. London: Richard Phillips.

Defra, 2004. Making space for water: developing a new government strategy for flood and coastal erosion risk management in England and Wales. London: Department for Food and Rural Affairs. Available from http://www.look-up.org.uk/2013/wpcontent/uploads/2014/02/Making-space-for-water.pdf [Accessed 21 June 2017]

Defra, 2013. Catchment based approach: Improving the quality of our water environment. London: Defra. Available from https://www.gov.uk/government/uploads/system/uploads/attachment_data/file/204231/pb139 34-water-environment-catchment-based-approach.pdf [Accessed 20 Oct 2016]

Environment Agency, 2013. The Arun and Western streams catchment abstraction licensing Strategy. Bristol: Environment Agency. Available from https://www.gov.uk/government/publications/arun-and-western-streams-catchmentabstraction-licensing-strategy [Accessed 12 July 2017].

Environment Agency, 2014. Working with natural processes to reduce flood risk. $R \& D$ framework: science report SC130004/R2. Bristol: Environment Agency. Available from https://www.gov.uk/government/uploads/system/uploads/attachment_data/file/338434/SC130 004_R1.pdf [Accessed 12 May 2017] 
Environment Agency, 2017. The Western Rother - summary. Available from http://environment.data.gov.uk/catchment-planning/OperationalCatchment/3533/Summary [Accessed, 15 April 2017]

Evans, E. J., 1976. The contentious tithe:The tithe problem and English agriculture, 17501850. London: Routledge \& Kegan Paul.

Evans, E. J., 1997. Tithes: Maps, apportionments and the 1836 Act: A guide for local historians: British Association for Local History.

Field, J., 1993. A history of English field-names. London: Addison Wesley Longman.

Fuller, R. M., 1987. 'The changing extent and conservation interest of lowland grasslands in England and Wales: a review of grassland surveys 1930-84'. Biological Conservation, 40, pp. 281-300.

Fussell, G. E., 1955. 'Crop nutrition in Tudor and early Stuart England'. Agricultural History Review, 3(2), pp. 95-106.

Golden Valley Study Group, 2016. The man who drowned the meadows: Rowland Vaughan, 1558-1627. Little Logaston: Logaston Press.

Harley, J. B., 1972. Maps for the local historian: A guide to British sources. London: National Council for Social Service.

Heywood, I., Cornelius, S., \& Carver, S., 2011. An introduction to geographical information systems (4th ed.). Harlow: Pearson.

Jarvis, M. G., et al., 1984. Soils and their use in South East England. Harpenden: Soil Survey of England and Wales.

Kain, R. J., \& Holt, H. M., 1983. 'Farming in Cheshire circa 1840: Some evidence from the tithe files'. Transactions of the Lancashire and Chesire Antiquarian Society, 82, pp. 22-57.

Kain, R. J., et al., 1995. The tithe maps of England and Wales: A cartographic analysis and county-by-county catalogue. Cambridge University Press.

Kain, R. J., \& Prince, H. C., 1985. The tithe surveys of England and Wales. Cambridge University Press.

Kain, R. J., \& Prince, H. C., 2000. Tithe surveys for historians. Chichester: Phillimore.

Kerridge, E., 1954. 'The sheepfold in Wiltshire and the floating of the watermeadows'. Economic History Review, 6(3), pp. 282-289.

Kerridge, E., 1969. Agrarian problems in the sixteenth century and after. London: George Allen \& Unwin.

Kondolf, G., et al., 2006. 'Process-based ecological river restoration: visualizing threedimensional connectivity and dynamic vectors to recover lost linkages'. Ecology and Society, 11(2), pp. 121-137. 
Lawton, J. H., et al., 2010. Making space for nature: a review of England's wildlife sites and ecological network. Report to Defra. Available from

http://webarchive.nationalarchives.gov.uk/20130402170324/http://archive.defra.gov.uk/envir onment/biodiversity/documents/201009space-for-nature.pdf [Accessed 12 May 2017]

Lewis-Sempel, J., 2015. Meadowland. The private life of an English field. London: Back Swan.

Lord Leckonfield, 1954. Petworth Manor in the seventeenth century. Oxford University Press.

Loudon, J. C., 1825. An encyclopaedia of agriculture. London: Longman.

Marcucci, D. J., 2000. 'Landscape history as a planning tool'. Landscape and Urban Planning, 49(1-2), pp. 67-81.

Marshall, W., 1798. The rural economy of the southern counties, 1798, vol 2 (Vol. 2). London: G. Nicol.

Martins, S. W. \& Williamson, T., 1994. 'Floated water-meadows in Norfolk: A misplaced innovation'. Agricultural History Review, 42(1), pp. 20-37.

McDonald, A., 2007a. 'The effect of management on the biodiversity of a recreated floodplain meadow in the upper Thames valley: a case study of Somerford Mead'. Fritillary, 5, pp. 79-95.

McDonald, A., 2007b. 'A brief history of Port Meadow and Wolvercote Common and Picksey Mead, and why their plant communities changed over the last 90 years'. Fritillary, 5, pp. 58-78.

Muir, R., 2003. 'On change in the landscape'. Landscape Research, 28(4), pp. 383-403.

Natural England, 2017. Countryside Stewardship: Higher Tier manual. Available from https://www.gov.uk/government/publications/countryside-stewardship-higher-tier-manual [Accessed 20 October 2017].

Natural England in partnership with the Environment Agency and Defra, 2014. Catchment sensitive farming evaluation report - Phases 1 to 3 (2006 - 2014) (C. E. T. E. Agency, Trans.). Available from http://publications.naturalengland.org.uk/publication/6510716011937792 [Accessed 15 October 2016]

Peterken, G., 2013. Meadows. Oxford: British Wildlife Publishing Ltd.

Prince, H. C., 1959. 'The tithe surveys of the mid-nineteenth century'. The Agricultural History Review, 7(1), pp. 14-26.

Rackham, O., 1986. The history of the countryside. London: Dent.

Riley, M., 2005. 'Silent meadows: The uncertain decline and conservation of hay meadows in the British landscape'. Landscape Research,30(4), pp. 437-458. 
Rothero, E., Lake, S., \& Gowing, D., 2016. Floodplain Meadows - Beauty and Utility. A Technical Handbook. Milton Keynes: Floodplain Meadows Partnership, Open University. Available from http://www.floodplainmeadows.org.uk/sites/www.floodplainmeadows.org.uk/files/Floodplain $\% 20$ Meadows\%20-\%20Beauty\%20and\%20Utility\%20A\%20Technical\%20Handbook.pdf [Accessed 15 October 2016]

Shand, P., et al., 2003. Baseline report series: 9. The lower greensand of southern England. British Geological Survey Commissioned Report CR/03/273C. Environment Agency National Groundwater \& Contaminated Land Centre. Technical Report NC/99/74/9 \& Product code: SCHO0207BLYG-E-P CR/03.

Sheail, J., 1980. Historical ecology: The documentary evidence. Cambridge: Institute of Terrestrial Ecology.

Smith, T. M., 2012. Enclosure and agriculturali improvement in north-west Lincolnshire from circa 1600 to 1850. Thesis (PhD) University of Nottingham. Available from http://eprints.nottingham.ac.uk/12489/1/Tom\%27s_Thesis_complete_\%28slimline\%29.pdf [Accessed 21 August 2017]

Smith, W., 1806. Observations on the utility, form and management of water meadows, and the draining and irrigation of peat bogs. Norwich: R. M. Bacon.

South Downs National Park Authority, 2013. Partnership management plan. Available from http://www.southdowns.gov.uk/wp-content/uploads/2015/01/SDNP-PartnershipManagement-Plan-2014-19.pdf [Accessed 12 July 2017]

Southern Water, 2017. Integrated water cycle management. Available from https://www.southernwater.co.uk/integrated-water-cycle-management [Accessed 12 July 2017]

Stearne, K., \& Cook, H., 2015. 'Water meadow management in Wessex: Dynamics of change from 1800 to the present day'. Landscape Research, 40(3), pp. 377-395.

Sylvester, D., 1958. 'The common fields of the coastlands of Gwent'. Agricultural History Review, 6(1), pp. 9-26.

Taylor, C., Smith, N., \& Brown, G., 2006. 'Rowland Vaughan and the origins of downward floated water-meadows: a contribution to the debate'. Landscape History, 28(1), pp. 35-51.

The National Trust, 1997. Petworth House, West Sussex. London: The National trust.

Vamplew, W., 1981. 'Tithes and agriculture: some comments on commutation'. Economic History Review, 34(1), pp. 115-119.

Vine, P. A. L., 1995. London's lost route to Midhurst. The Earl of Egremont's navigation. Stroud, Gloucestershire: Alan Sutton.

Whitehead, J., 1981. 'North Meadow, Cricklade'. Wiltshire Archaeological Magazine, 76, pp. 129-140. 
Wildlife Trusts, 2017. A living landscape. Available from http://www.wildlifetrusts.org/living-landscape [Accessed 12 July 2017]

Williams, M., 1970. The draining of the Somerset Levels. Cambridge University Press.

Williams, M., 1972. 'The enclosure of waste land in Somerset, 1700-1900'. Transactions of the Institute of British Geographers, 57, pp. 99-123.

Wright, T., 1789. An account of the advantages and methods of watering meadows by art. Cirencester: S. Rudder.

Wyndham, H. A., 1950. A family history 1688-1837. The Wyndhams of Somerset, Sussex and Wiltshire. London: Oxford University Press.

Young, A., 1813. General view of the agriculture of the county of Sussex. London: Sherwood, Neely and Jones. 


\section{Figure captions}

Figure 1: Location map of study area. Contains OS data (C) Crown copyright and database rights 2017.

Figure 2: Extract from Richard Treswell's map of 1610 that shows nine common meadows on the northern side of the Rother. Reproduced with the kind permission of Lord Egremont.

Figure 3: Extract from 'Plan of Meadows by Lord Egremont in the years 1794, 1795 \& 1796' (Petworth Archives PHA 3232). The red lines show the open drains and the dotted lines show covered drains that pass under the river or roads. Sluices labelled ' $S$ ' could be closed in order to flood Hole, Rough Piece and Pike Shoot meadows 'in a few hours in the driest season'. Reproduced with the kind permission of Lord Egremont.

Figure 4: Extract from 'Plan of the Navigable Line of the River Rother, in the County of Sussex; (including the Haslingbourne Cut) 1797' (Petworth Archives PHA 3504). Areas marked in red show new cuts whilst areas marked in yellow are areas to be infilled. Owners and occupiers of the common meadows are listed. Reproduced with the kind permission of Lord Egremont.

Figure 5: Common meadows along the lower Rother based on the Rother Navigation plans of 1797.

Figure 6: Extract from 'Sutton Common Meadow as taken by Thomas P. Upton, August $11^{\text {th }}$ 1807 beginning at the lower end of the meadow and going upwards' (Petworth Archives PHA 14885). The existing pieces within the meadow are depicted in black, the proposed changes are shown in brown. Reproduced with the kind permission of Lord Egremont.

Figure 7: Extract from 'A correct plan of Ambersham Meadow with reference to the several pieces as marked out in the said meadow situate in the Tithing of Ambersham in the Parish of Steep in the County of Southampton' by William Barlow, 1813 (Cowdray Mss 1700). Areas depicted in colour indicate permanent ownership whereas other areas record either partnerships where annual exchange between individuals was carried out or rights to herbage were claimed for the same plot in alternate years. Reproduced with the kind permission of West Sussex Record Office.

Figure 8: Extract from 'Plan of 1814 by William Barlow of Ambersham Meadow showing several pieces marked out by the proprietors when they agreed to consolidate their respective claims' (Cowdray Mss 1703). Small squares represent posts or stones demarcating the 
alignment of the boundaries with the owner's initial written on the appropriate side of the symbol, for example ' $S$ ' for Mr Stenning and ' $D$ ' for Mr Dennett, as illustrated below. Reproduced with the kind permission of West Sussex Record Office.

Figure 9: Two 'dole' stones discovered during fieldwork in the floodplain meadows of Coates parish. The initials ' $\mathrm{I}+\mathrm{F}$ ' and ' $\mathrm{T}+\mathrm{S}$ ' indicate ownership to the left and right of each stone, though the names of these owners has, as yet, to be discovered. Conceivably, their survival may be due to their prominence in nodal positions within the arrangement of the strips such that annual setting out of the plots would have used these markers as a baseline reference.

Figure 10: Land use based on the tithe surveys of the 1840s. Fingers of meadow reach up into the neighbouring farmland along tributaries of the Rother. Together they represented the single most continuous agricultural land use type in the catchment, presenting a corridor of meadows that has since almost totally disappeared. The descriptions such as 'Good turnip land' etc. have been added from the tithe files.

Figure 11: Lady, Coates, Hesworth and Steeple meadows and their owners from the tithe map of 1840. These meadows represent the most complete arrangement of strips to survive into the 1840s. The red squares have been added to indicate the location of the 'dole' stones discovered during fieldwork. The tithe map is reproduced with the kind permission of West Sussex Record Office.

Figure 12: The meadows of Coates parish showing occupants and the surrounding area.

Figure 13: A reconstruction of the water management system of the meadows between Shopham Bridge and Fittleworth Bridge using the Watershed tools available in Golden Software's Surfer ${ }^{\circledR}$ surface mapping system. The streams (blue lines) show the paths that water would take across the LiDAR data and do not indicate actual surface flow. The red dots are suggested locations for flow control structures (sluices, hatches, boards etc.).

\section{Table captions}

Table 1: Common meadows as identified on the Rother Navigation plan of 1797, listed in order roughly from Midhurst downstream to the Rother's confluence with the Arun. 


\section{Plates}

Plate 1: Bank erosion on the Rother caused by livestock. Note also the homogenous sward of sown grass on the floodplain.

\footnotetext{
${ }^{i}$ The benefits of populating a GIS with tithe survey data were first demonstrated during the 1990s (Pearson, Carter, \& Gallmeier 1994; Pearson \& Collier 1998) and later employed to tackle research questions in agricultural history (Pearson \& Collier 2002).

ii LiDAR (Light Detection And Ranging) is a method of remote sensing that collects high resolution digital elevation models (DEMs) using aircraft-mounted lasers. Accuracies and resolutions will vary depending on the flying height of the aircraft (Heywood et al. 2011). For the study area, a mix of $1 \mathrm{~m}$ and $2 \mathrm{~m}$ resolution LiDAR data has been used.
}

iii Taylor et al. (2006) argue that the artificial irrigation of meadows was already established practice before the publication of Vaughan's work and indeed it is likely that irrigation systems of some sophistication would have been introduced by the monastic houses, particularly the Cistercians, by the twelfth century.

${ }^{\text {iv }}$ Not to be confused with his father Arthur Young FRS who was a renowned agricultural writer during the latter half of the $18^{\text {th }}$ century.

$\checkmark$ Watering meadows was established practice in the county. Arthur Young in his General View of the Agriculture of the County of Sussex (1813) praised the employment of watered meadows in western Sussex, 'that admirable practice of watering their meadows in a regular manner, is very well understood, and successfully practised' (p.222). However, his comments appear to be limited to the Lavant, a chalk stream to the north of Chichester and no mention is made of the Rother.

vi Such schemes were not guaranteed to succeed. At nearby Burton Park, the water management system, though undertaken 'in a very skilful manner', had little positive effect. Indeed, according to the Reverend Nicholas Turner who lived near the spot where the works had been carried out was of the opinion that "watering this land has not done one atom of good too it' (Young 1813, p.225).

vii The records of the Rother Navigation (Estate office number OF13) form part of the archives of the southern estates of the Wyndham family at Petworth House. Although remaining at Petworth, they are under the care of the Library and Archives Committee of West Sussex County Council, and may be consulted in the West Sussex Record Office at Chichester providing application is made in advance.

viii Petworth Archives OF13/12/22 Rother Navigation: Estimates and expenses of making the Rother navigation from Stopham to Midhurst.

ix The estimates for building the navigation included the cutting of back drains at a cost of $£ 110$ (Petworth Archives OF 13/12/22 Rother Navigation).

x Petworth Archives PHA 3232 ' 1796 by G.W.'

xi Petworth Archives OF 13/16b/22-24 Correspondence between James Upton Tripp and William Tyler, and John Ibbetson, concerning damage done to meadows at Sutton resulting from the navigation. 5 June $1800-11$ October 1801.

xii Petworth Archives OF13/16b/35-48. Correspondence between Earl of Egremont, Thomas P. Upton, William Tyler, and Charles Biddulph, concerning damage to Merrifield Meadow in Burton resulting from the Navigation. 11 April - 5 May 1819.

xiii Petworth Archives PHA 3504 'Plan of the Navigable Line of the River Rother, in the County of Sussex; (including the Haslingbourne Cut) 1797' (20 in. to $1 \mathrm{~m}$. 28.5 x 203") is the fair drawing of the draft plan PHA 3505 that does not have a title, date or surveyor named. The latter is of great value as it appears to show posts within the common meadows demarcating the strips of those who owned pieces in each meadow. 
xiv Petworth Archives PHA 14885 'Sutton Common Meadow as taken by Thomas P. Upton, August $11^{\text {th }} 1807$ beginning at the lower end of the meadow and going upwards'; PHA 14886 'North Common Meadow as measured by Thomas P. Upton, August, 1807 beginning at the lower end and going upward'; PHA 14887 Plan of Byworth Meadow as measured by Thomas P. Upton, Sept.1807 beginning at the lower end and going upward'.

${ }^{x v}$ Petworth Archives PHA 14889 'A Plan of North Common Meadow by a new Arrangement set out by Thomas P. Upton, Sept. 22 nd 1817 '; PHA 14888 'A Plan of Upper Common Meadow by a new arrangement set out by Thomas P. Upton, $4^{\text {th }}$ August $1817^{\prime}$.

${ }^{x v i}$ Cowdray Mss 1700 'A correct plan of Ambersham Meadow with reference to the several pieces as marked out in the said meadow situate in the Tithing of Ambersham in the Parish of Steep in the County of Southampton’ by William Barlow, 1813.

xvii Cowdray Mss 1703 'A correct plan of Ambersham Meadow situate in the Tithing of Ambersham in the Parish of Steep in the County of Southampton with a reference to the Several Pieces marked out by the Proprietors when they agreed to consolidate their respective Claims' by William Barlow, August $2^{\text {nd }} 1814$.

xviii It is interesting to note that not all the symbols are labelled with an initial or at least a surname beginning with the letter ' $\mathrm{J}$ ' is given a symbol resembling the letter ' $\mathrm{I}$ ' with serifs together with a central horizontal bar. This may hark back to the custom of using symbols rather than letters during lot casting as at Alveston, Warwickshire, where an identical symbol denotes the letter ' $\mathrm{J}$ '

xix Cowdray Mss 1705 ' A correct Plan of Umbley Meadow situate in the tithing of Ambersham in the Parish of Steep in the County of Southampton with a reference to the several pieces as marked out by the proprietors when they agreed to consolidate their respective claims by William Barlow, ${ }^{\text {nd }}$ August 1814.

${ }^{x x}$ Other terms used in apportionments include: One piece in Coates Meadow; Piece in Clapper or Mill Common; Long Brook; A changeable piece in Clapper Common Meadow; Suckling Stall Brook; One piece of Coates Meadow (North of Ditch); One piece of Coates Meadow (South of Ditch); Piece in Byworth Mead.

xxi National Archives IR18 tithe file for the parish of Petworth, Sussex.

xxii The ninth Earl of Northumberland emparked a common wood despite objections raised by his tenants. The park spread rapidly northwards with over 800 acres enclosed into a new park.

xxiii Apportioning rent-charges for Lammas lands or commons of this type presented a problem to the Tithe Commissioners. Being owned in severalty for only a part of the year and from Lammas to Candlemas for common grazing the rent-charge map has been apportioned among two or more owners of the same plot of land (p.24). At Petersfield it was estimated that between one to one and a half tons of hay, worth at least £3 per ton at a moderate price, were harvested annually. To the value of the hay was added the value of the pasturage during the remainder of the year when the 'meadow land is not kept up for hay'. The sum of $£ 310 /-$ per acre was the final estimate for the gross produce of the meadow and pasture land. Apparently, the land was frequently let for $£ 4$ per acre.

xxiv No evidence has been found to confirm that drowner, waterman, or meadman were in use as formal occupations for residents within the Rother valley. However, these terms appear widely in the broad literature of wet meadows across England and it is reasonable to assume that, at least in an informal capacity, one or more were associated with labourers of the water meadows along the Rother.

xxv Petworth Archives PHA 3606 'A Plan of the Estate belonging to the Earl of Egremont of Petworth, Tillington, North Chapel, Lurgashall, Kirdford, Egdean \& Fittleworth in the County of Sussex. Surveyed in the Year 1779 by James Crow'. 
Figure 1: Location map of study area

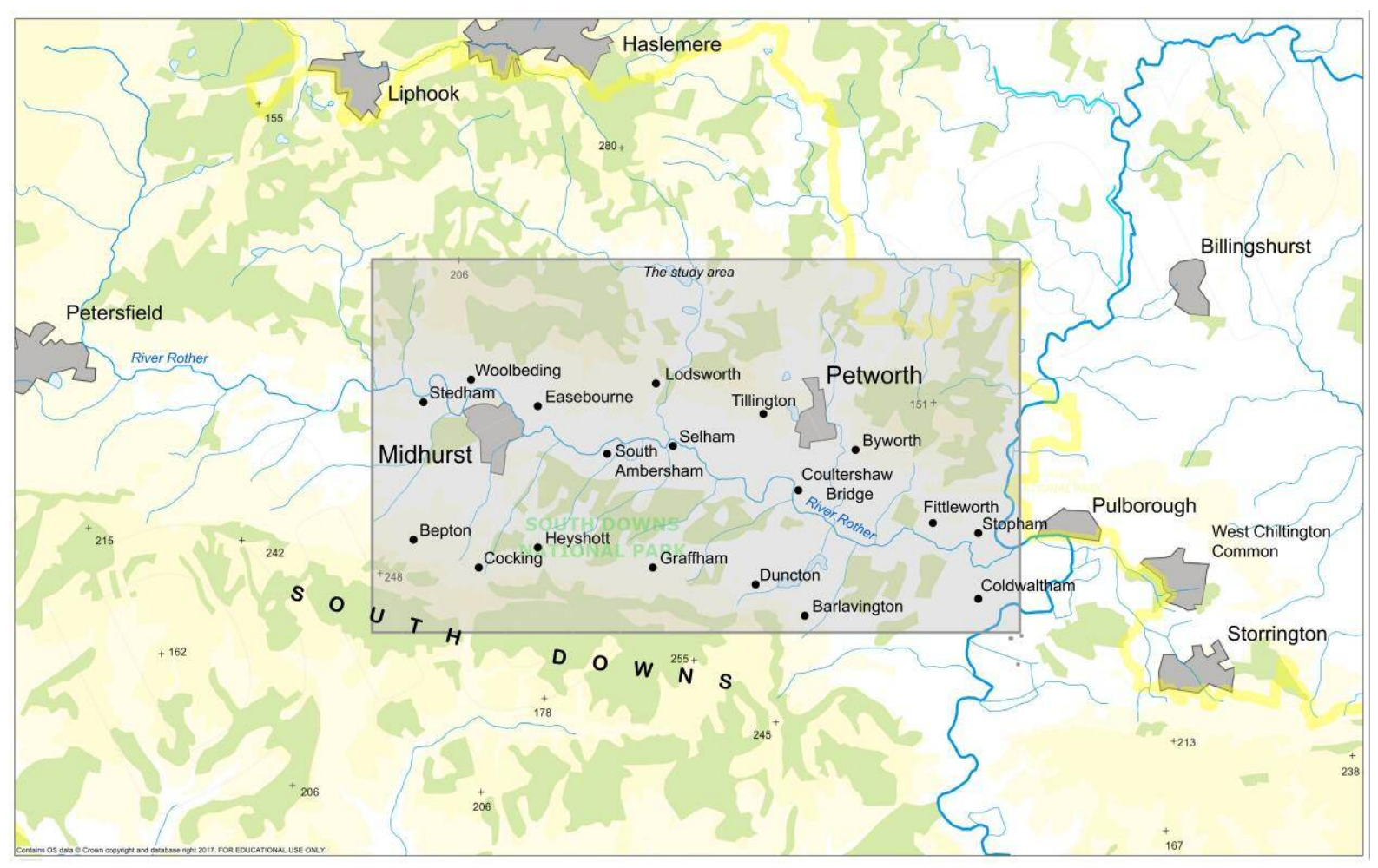


Figure 2:

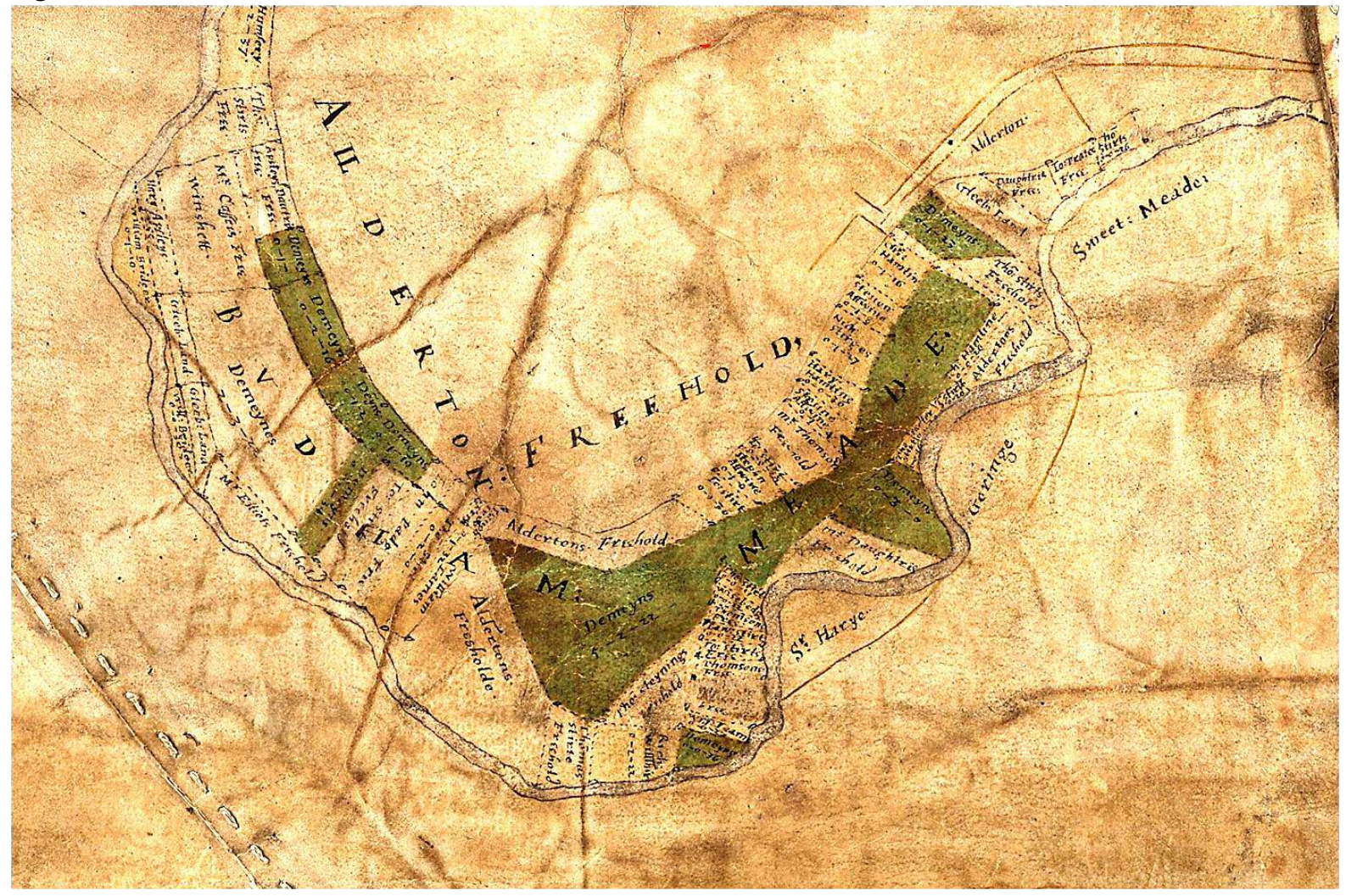


Figure 3:

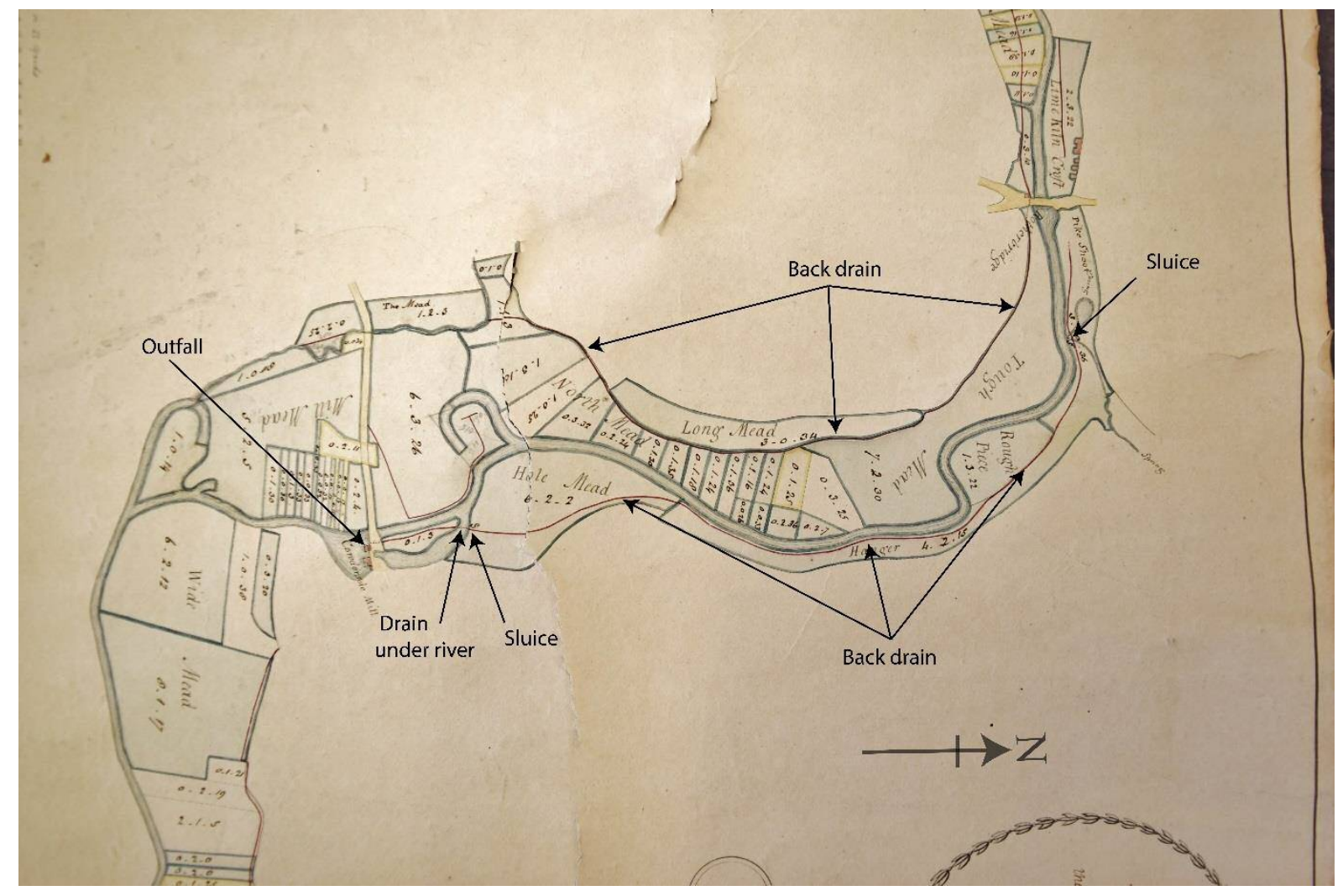


Figure 4:

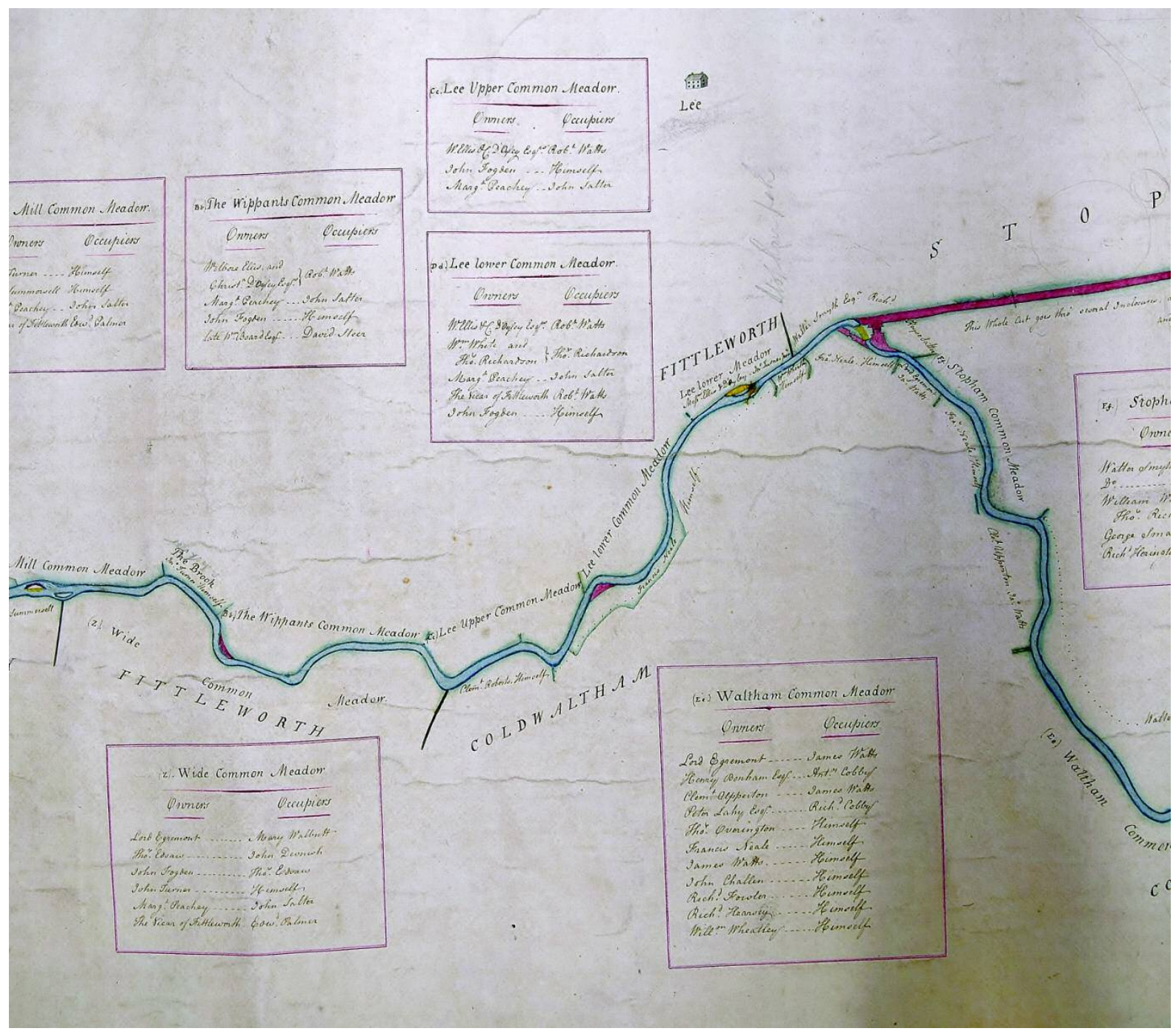


Figure 5:

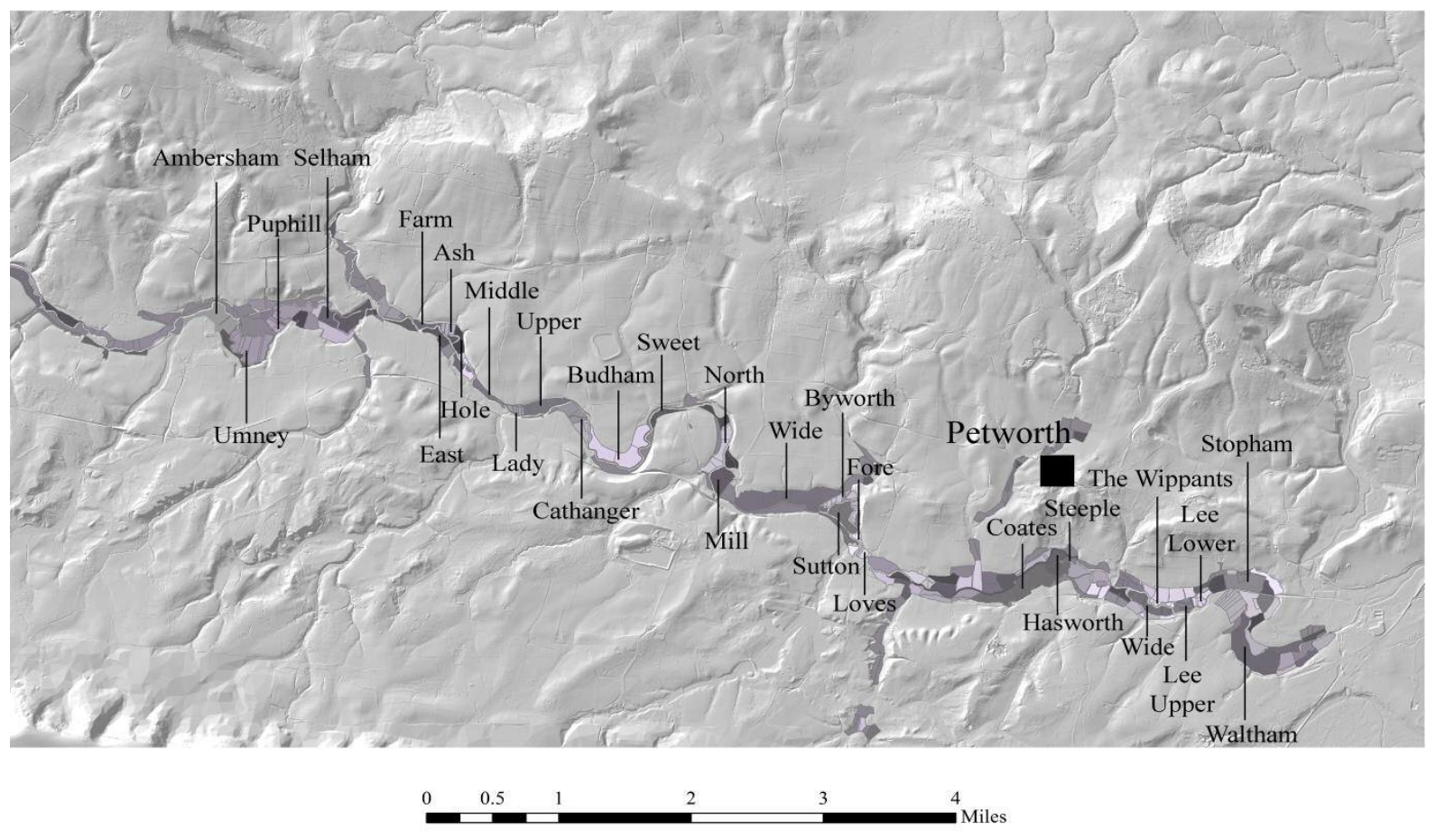


Figure 6:

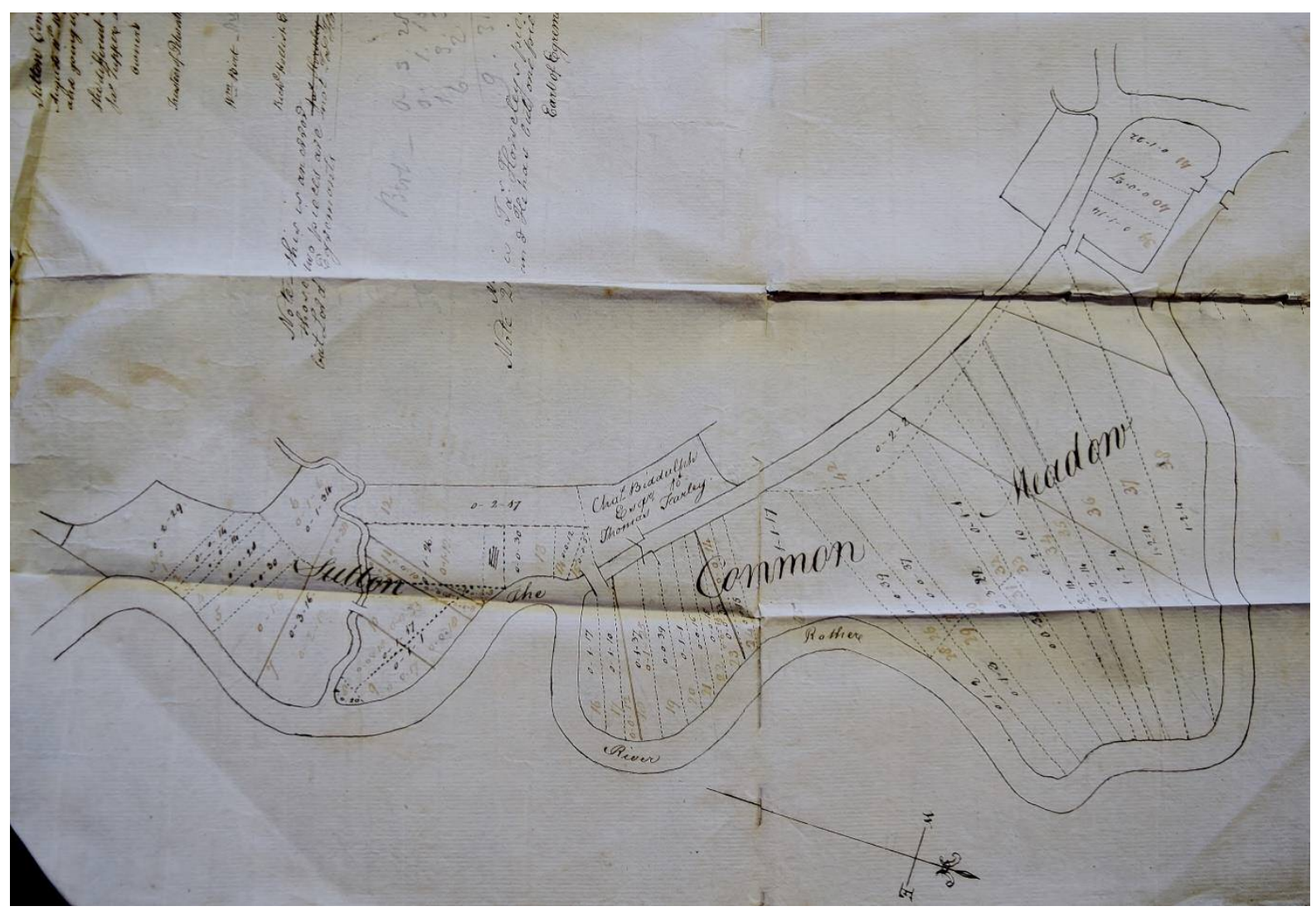


Figure 7:

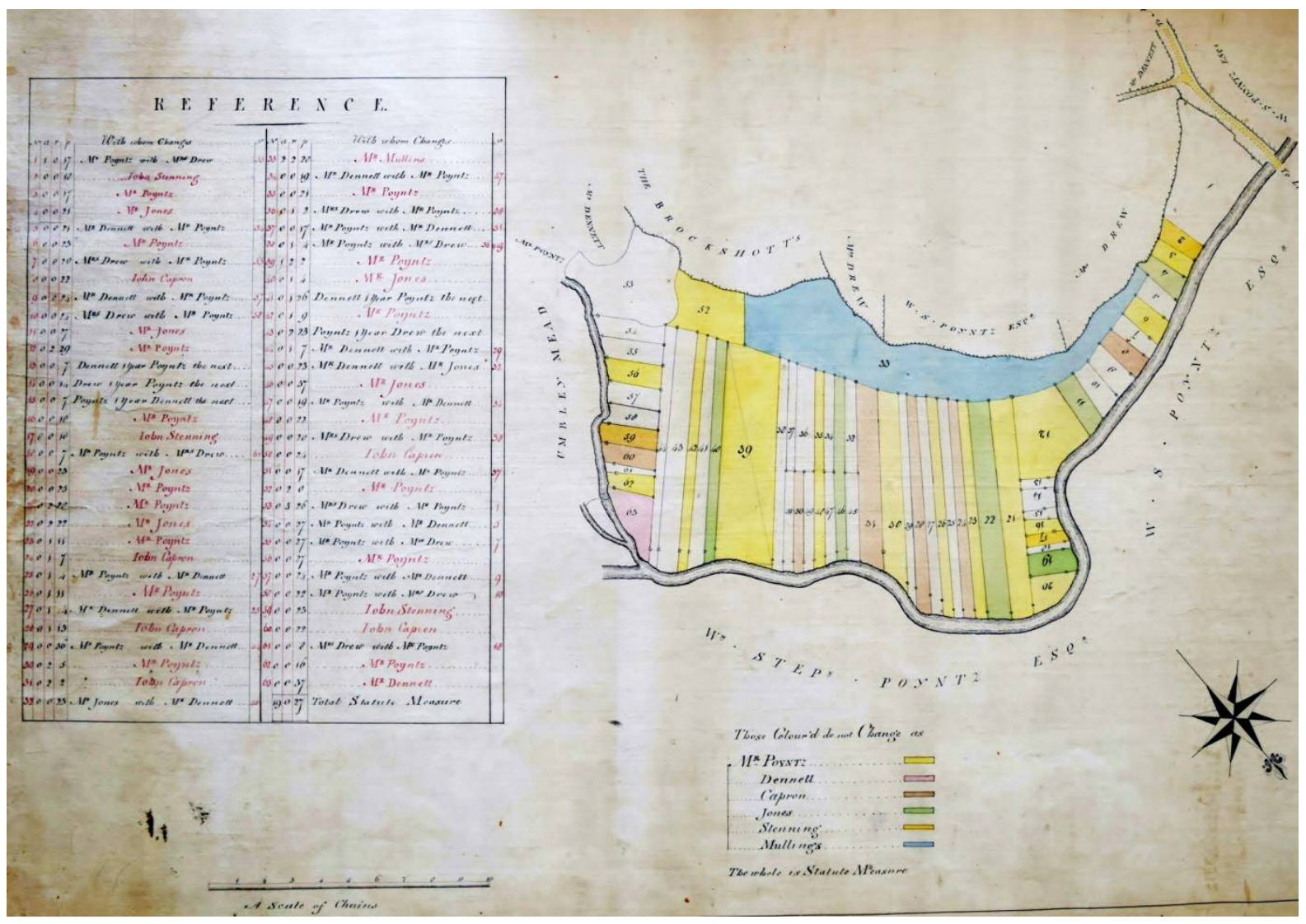


Figure 8:

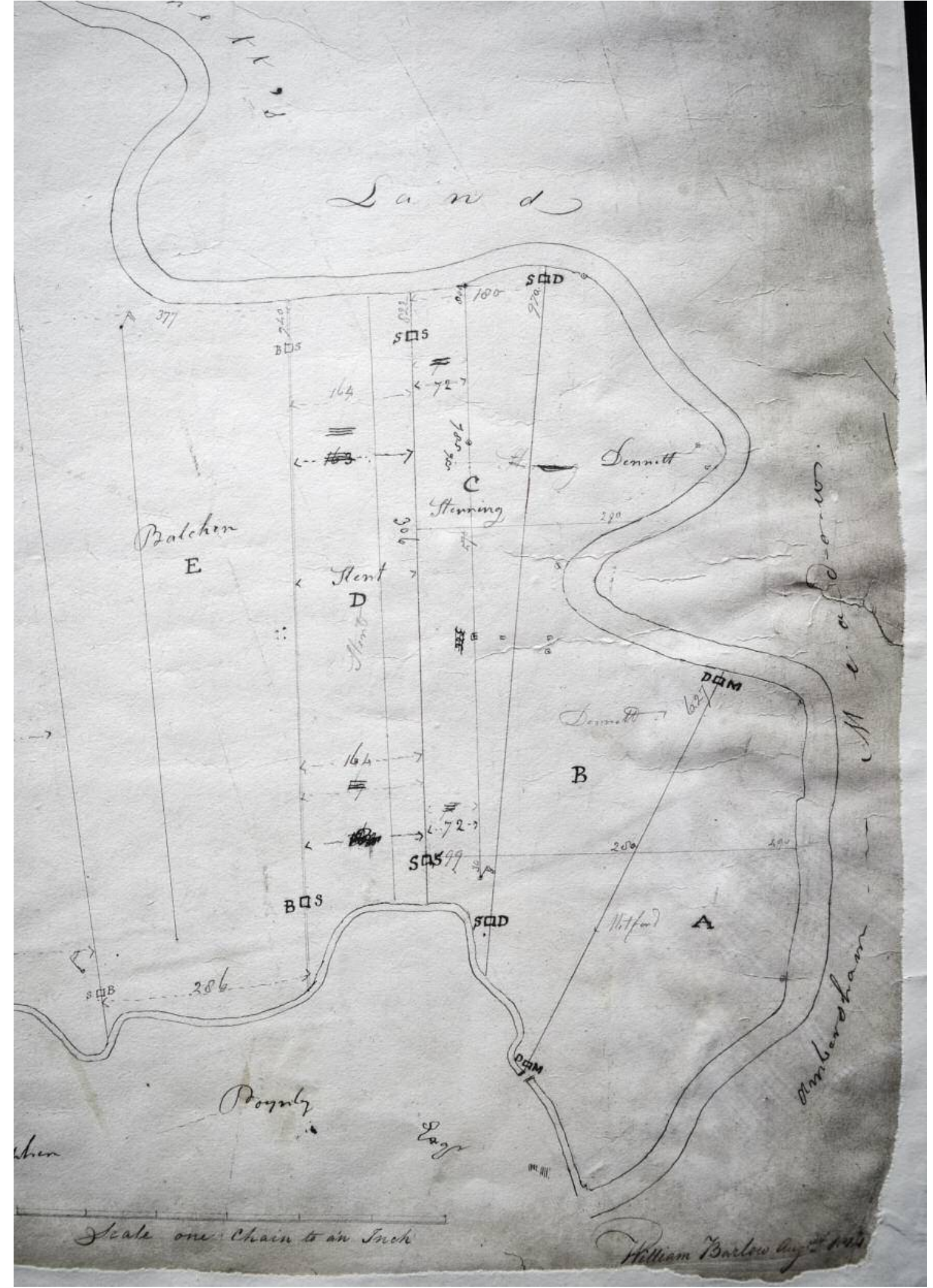


Figure 9 (a) and (b):
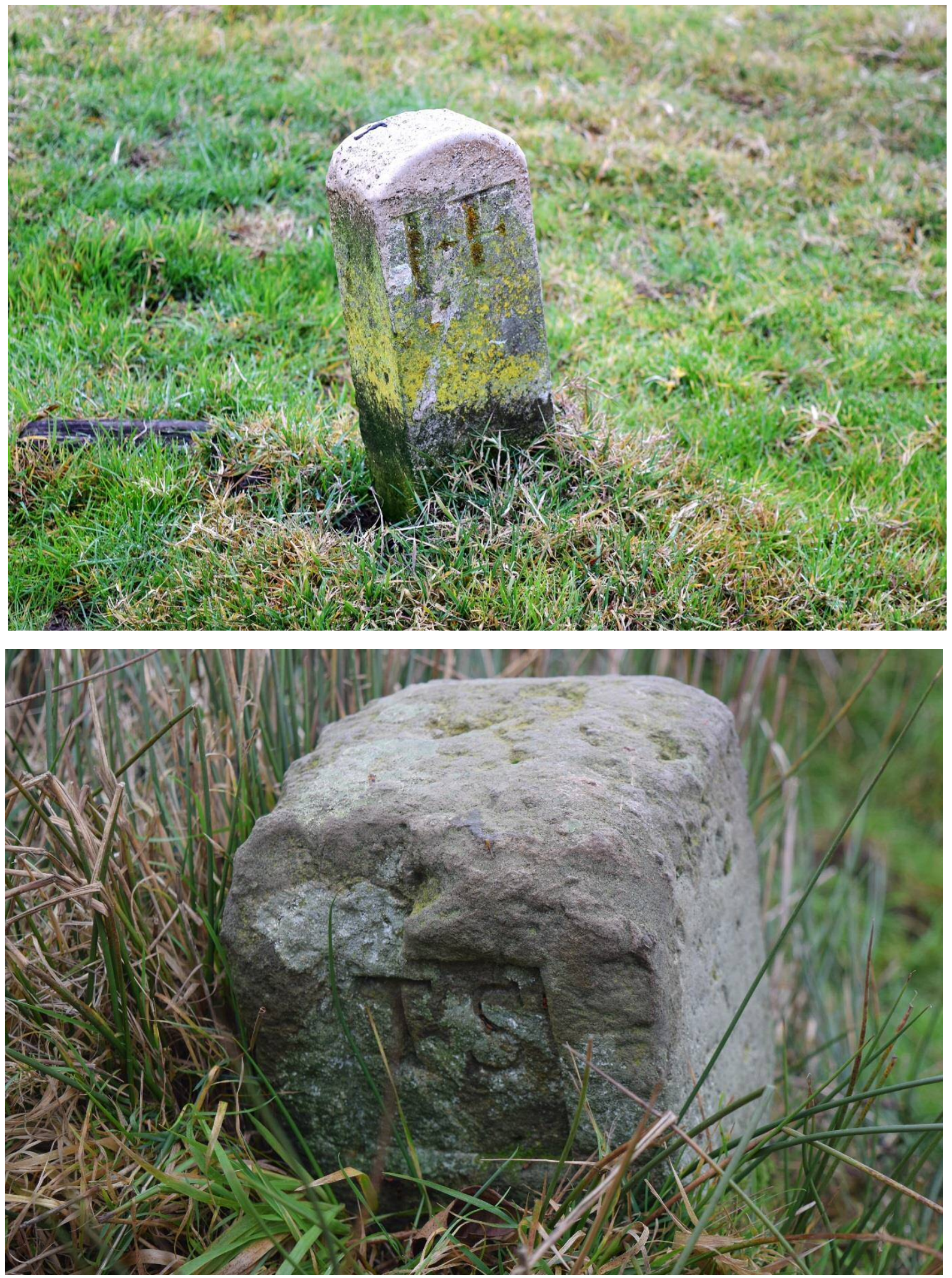
Land use of the western Rother c.1840 based on the tithe surveys

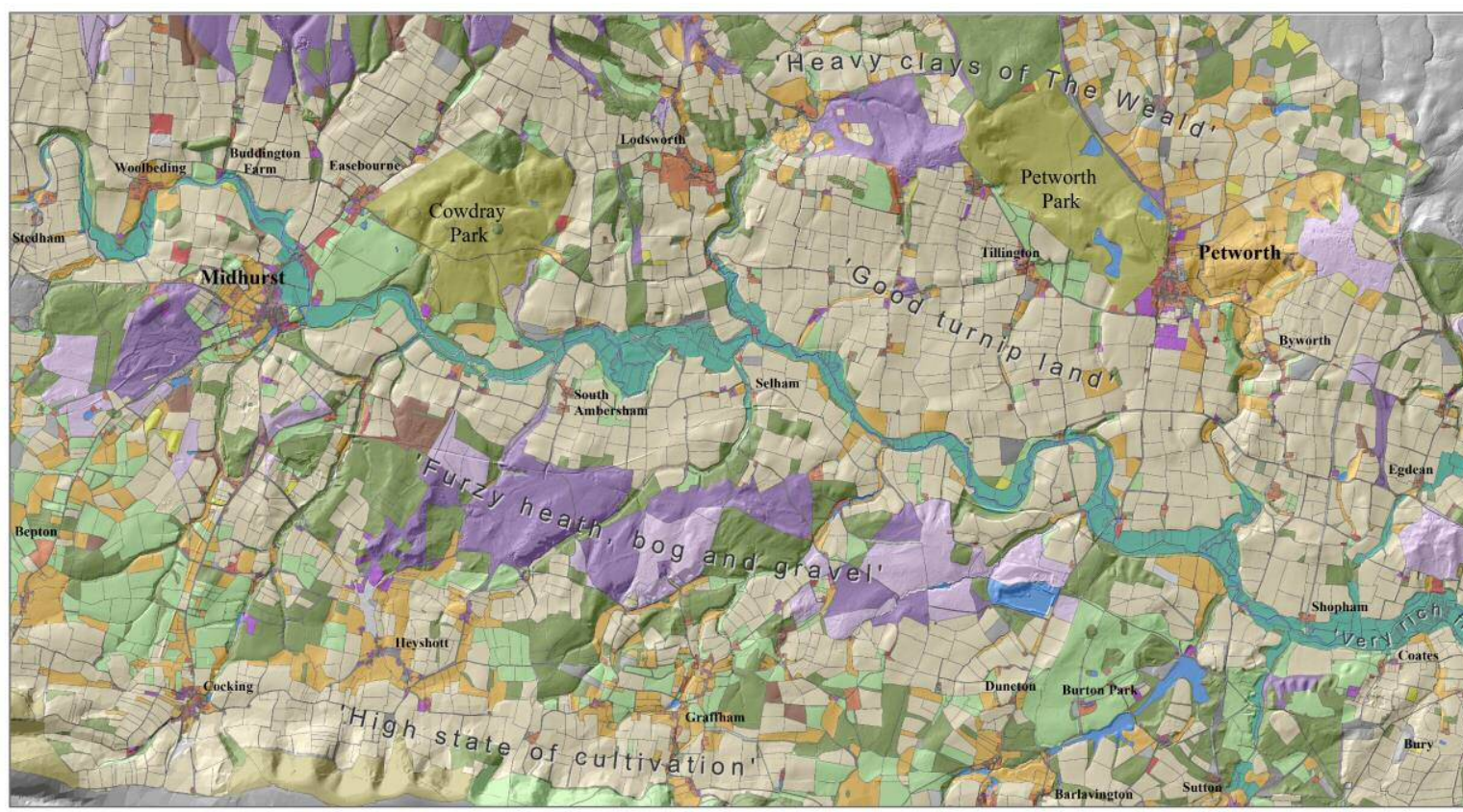

\begin{tabular}{|c|c|c|c|}
\hline $\begin{array}{l}\text { Floodplain } \\
\text { meadow }\end{array}$ & Pasture & Common & Woodland \\
\hline Dry meadow & Parkland & Heath & Water \\
\hline Arable & Downland & Garden & Buildings \\
\hline
\end{tabular}

Figure 10: 
Figure 11:

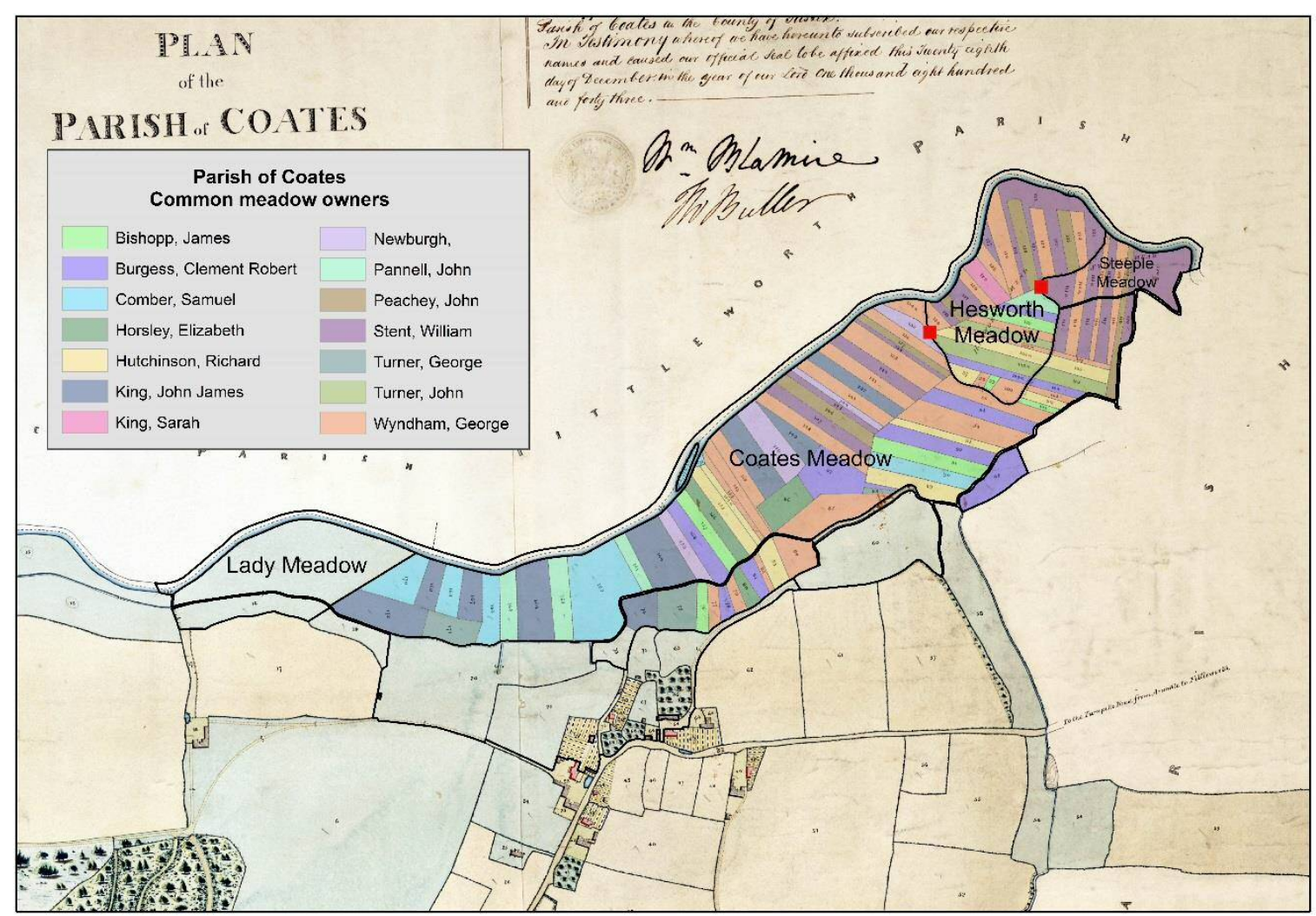




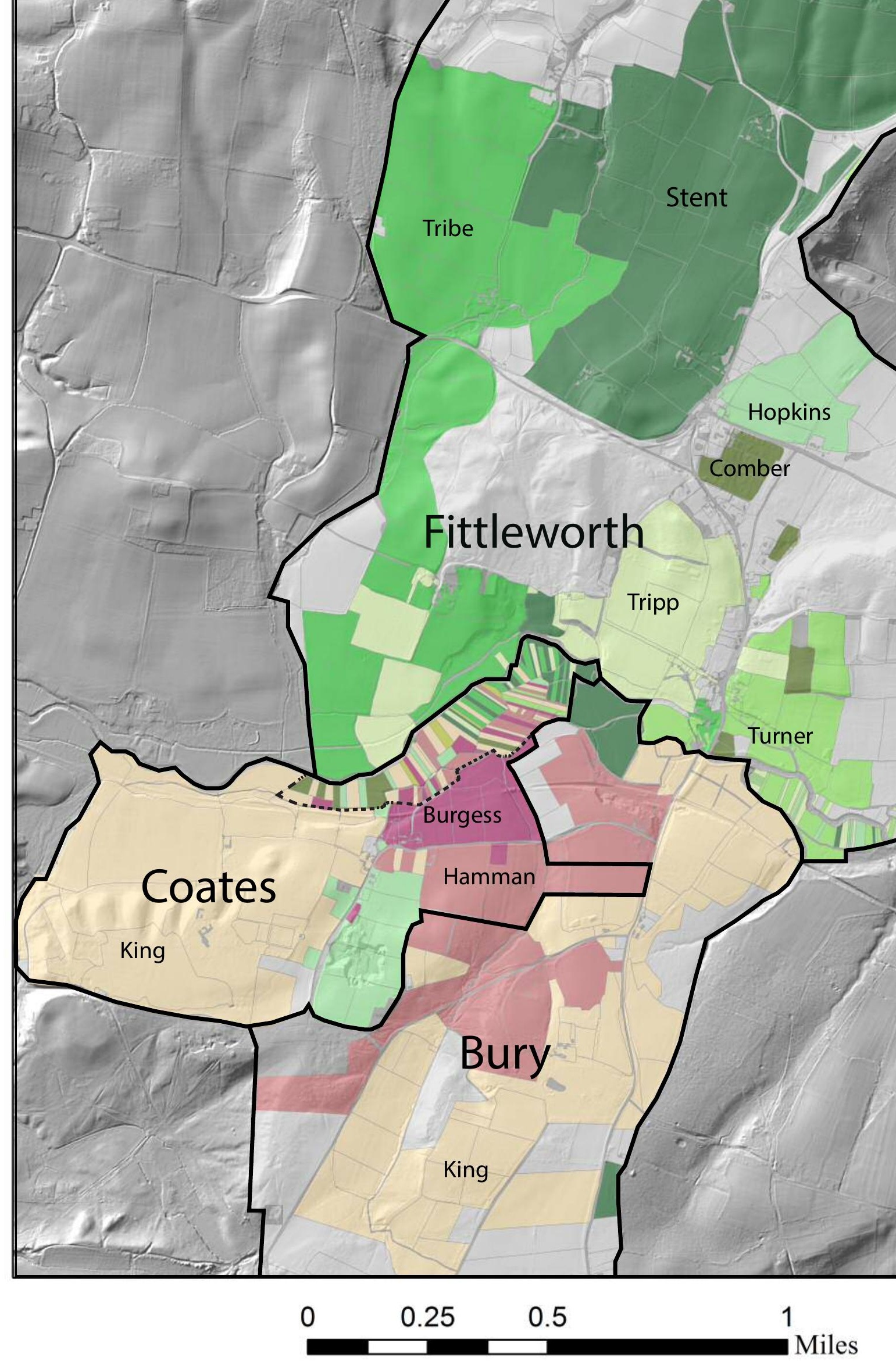




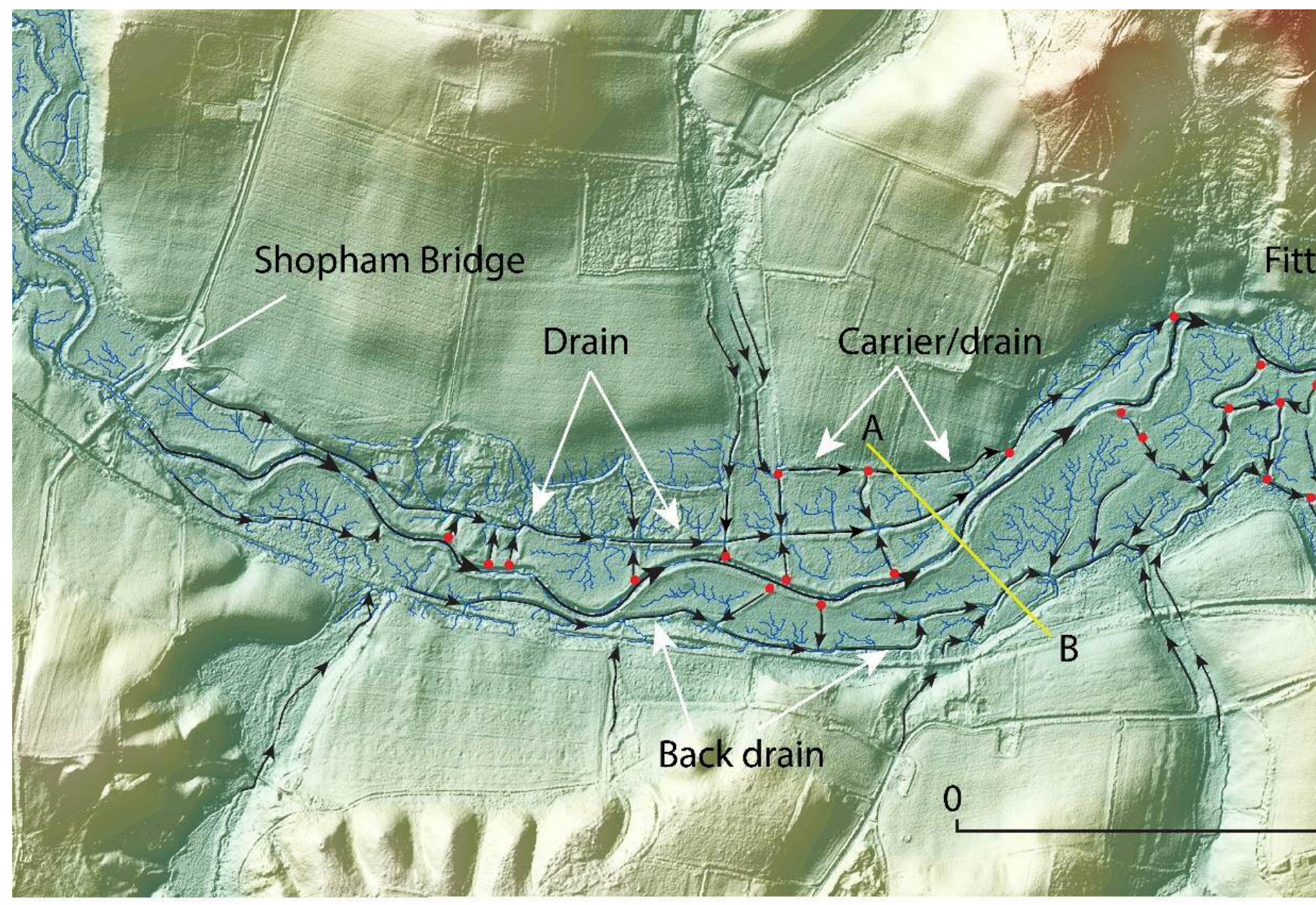

Profile A - B

Figure 13

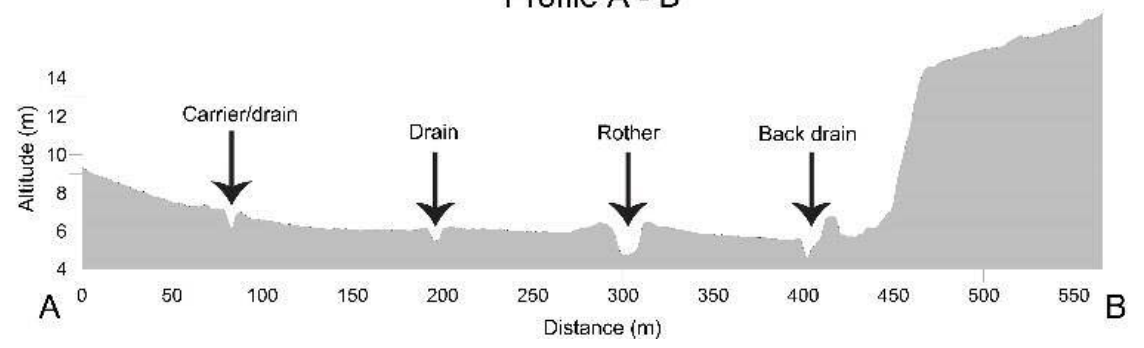


Table 1:

\begin{tabular}{|l|l|l|}
\hline Common Meadow & No. of owners & No. of occupants \\
\hline Easebourne & 13 & 13 \\
\hline Ambersham & 7 & 7 \\
\hline Umney & 7 & 7 \\
\hline Puphill & 4 & 4 \\
\hline Selham & 4 & 4 \\
\hline Farm & 1 & 1 \\
\hline East & 6 & 6 \\
\hline Ash & 8 & 7 \\
\hline Hole & 3 & 4 \\
\hline Middle & 3 & 4 \\
\hline Lady & 4 & 5 \\
\hline Upper & 11 & 13 \\
\hline Cathanger & 2 & 4 \\
\hline Budham & 9 & 13 \\
\hline Sweet & 5 & 7 \\
\hline North & 2 & 8 \\
\hline Mill & 3 & 3 \\
\hline Wide & 5 & 11 \\
\hline Sutton & 13 & 12 \\
\hline Byworth & 8 & 11 \\
\hline Fore & 6 & 5 \\
\hline Loves & 4 & 5 \\
\hline Coates & 13 & 15 \\
\hline Hasworth & 4 & 5 \\
\hline Steeple & 4 & 5 \\
\hline Wide & 6 & 6 \\
\hline The Wippants & 4 & 4 \\
\hline Lee Upper & 5 & 5 \\
\hline Lee Lower & 6 & 5 \\
\hline Waltham & 11 & \\
\hline Stopham & 5 & \\
\hline & & \\
\hline
\end{tabular}

